\title{
Early and middle Matuyama geomagnetic excursions recorded in the Chinese loess-paleosol sediments
}

\author{
Tianshui Yang ${ }^{1,2}$, Masayuki Hyodo ${ }^{2}$, Zhenyu Yang ${ }^{3}$, Lin Ding ${ }^{1}$, Jianli Fu ${ }^{4}$, and Toshiaki Mishima ${ }^{5}$ \\ ${ }^{1}$ Institute of Tibetan Plateau Research, Chinese Academy of Sciences, Beijing 100085, China \\ ${ }^{2}$ Research Center for Inland Seas, Kobe University, Kobe 657-8501, Japan \\ ${ }^{3}$ Department of Earth Sciences, Nanjing University, Nanjing 210093, China \\ ${ }^{4}$ Institute of Geomechanics, Chinese Academy of Geological Sciences, Beijing 100081, China \\ ${ }^{5}$ Center for Advanced Marine Core Research, Kochi University, Kochi 783-8502 Japan
}

(Received September 27, 2006; Revised January 11, 2007; Accepted January 15, 2007; Online published July 20, 2007)

\begin{abstract}
A detailed paleomagnetic and rock-magnetic investigation on the early and middle Matuyama loess-paleosol sediments has been carried out at the Baoji section, Shaanxi province, southern Chinese Loess Plateau. Our new magnetostatigraphy revises the position of the lower Olduvai boundary from L27 to S26. Seven shortlived geomagnetic excursions, tentatively named as E1, E2, E3, E4, E5, E6, and E7, have been recognized in the L13, S22, L26, L27, S29, and upper and middle parts of L32, respectively. Results of the anisotropy of low-field magnetic susceptibility (AMS) show that the studied loess-paleosol sediments retain the primary sedimentary fabric. Rock magnetic experiments reveal that the sediments from the excursional and polarity transitional intervals have the same magnetic characteristics as those from the surrounding normal and reversed polarity intervals. Assuming a constant accumulation rate between polarity boundaries, these seven excursions are estimated to be at about $1.11 \mathrm{Ma}(\mathrm{E} 1), 1.58 \mathrm{Ma}(\mathrm{E} 2), 1.92 \mathrm{Ma}(\mathrm{E} 3), 2.11 \mathrm{Ma}(\mathrm{E} 4), 2.25 \mathrm{Ma}(\mathrm{E} 5), 2.35$ Ma (E6), and 2.42 Ma (E7) Ma. The E1 and E2 in the middle Matuyama Chron can be correlated with the Punaruu and Stage 54 (Gilsa) excursions, respectively. The E4, E5, and E7 in the early Matuyama Chron can be correlated with the Réunion II, Réunion I, and cryptochron C2r.2r-1 (X-subchron), respectively. The E3 in the lower Olduvai subchron and E6 in the early Matuyama Chron have no comparable events. At present they can only be correlated with the anomalous directions observed in the Osaka Bay core (Biswas et al., 1999). Therefore, further investigations are necessary to support their global occurrences. The present result together with the two late Matuyama excursions dated at about $0.89 \mathrm{Ma}$ and $0.92 \mathrm{Ma}$ (Yang et al., 2004) show that the Baoji section yields at least nine Matuyama excursions which, along with the results of the study, suggests that eight excursions occur at 0.9-2.2 Ma (Channell et al., 2002), thereby providing evidence that the short-lived geomagnetic excursions may also be a basic characteristic of the geomagnetic field during the Matuyama Chron. Key words: Geomagnetic excursion, paleomagnetism, magnetostratigraphy, loess, Matuyama Chron, Olduvai, Punaruu, Stage 54, Réunion, cryptochron C2r.2r-1.
\end{abstract}

\section{Introduction}

The geomagnetic excursion is an important systematic and distinct component of the Earth's magnetic field variability between field reversals, showing a larger swing of the geomagnetic field beyond the range of secular variation, i.e., the virtual geomagnetic pole (VGP) latitude deviates more than $45^{\circ}$ from the normal position (e.g., Merrill and McFadden, 1994; McElhinny and McFadden, 1997).

Recent paleomagnetic studies have recognized numerous geomagnetic excursions that occurred in the Brunhes Chron (e.g., Langereis et al., 1997; Lund et al., 2001, 2006; Singer et al., 2002; Oda, 2005); in contrast, the number of papers reporting on the Matuyama Chron is much smaller, and more research is clearly necessary.

Loess-paleosol sequences in the Chinese Loess Plateau (CLP) consist of aeolian dust originating from the dry

Copyright (c) The Society of Geomagnetism and Earth, Planetary and Space Sciences (SGEPSS); The Seismological Society of Japan; The Volcanological Society of Japan; The Geodetic Society of Japan; The Japanese Society for Planetary Sciences; TERRAPUB deserts of the north and northwest (Liu, 1985). Loesses are mainly deposited under the cold and dry conditions of the East Asian winter monsoon system (glacial), and paleosols are formed under the warm and moist conditions of the summer monsoon (interglacial). The nearly continuous loesspaleosol sediments provide the most continuous terrestrial paleoclimatic and magnetostratigraphic records for the last 2.6 Myr (e.g., Evans and Heller, 2001). Recently, several researchers have continued investigations on the underlying red clay (Sun et al., 1998; Ding et al., 1998, 2001; Qiang et al., 2001; Guo et al., 2002), and the initiation of aeolian dust deposition has been extended back to more than $22 \mathrm{Ma}$, marking the onset of the present-day East Asian monsoon system (Guo et al., 2002).

Following the first establishment of magnetic polarity stratigraphy in Luochuan using borehole samples (Heller and Liu, 1982), magnetic studies were carried out in quick succession over the whole CLP, and major magnetozones from the Gauss to Brunhes have been established at many sites, including Luochuan (Heller and Liu, 1984), Xifeng 


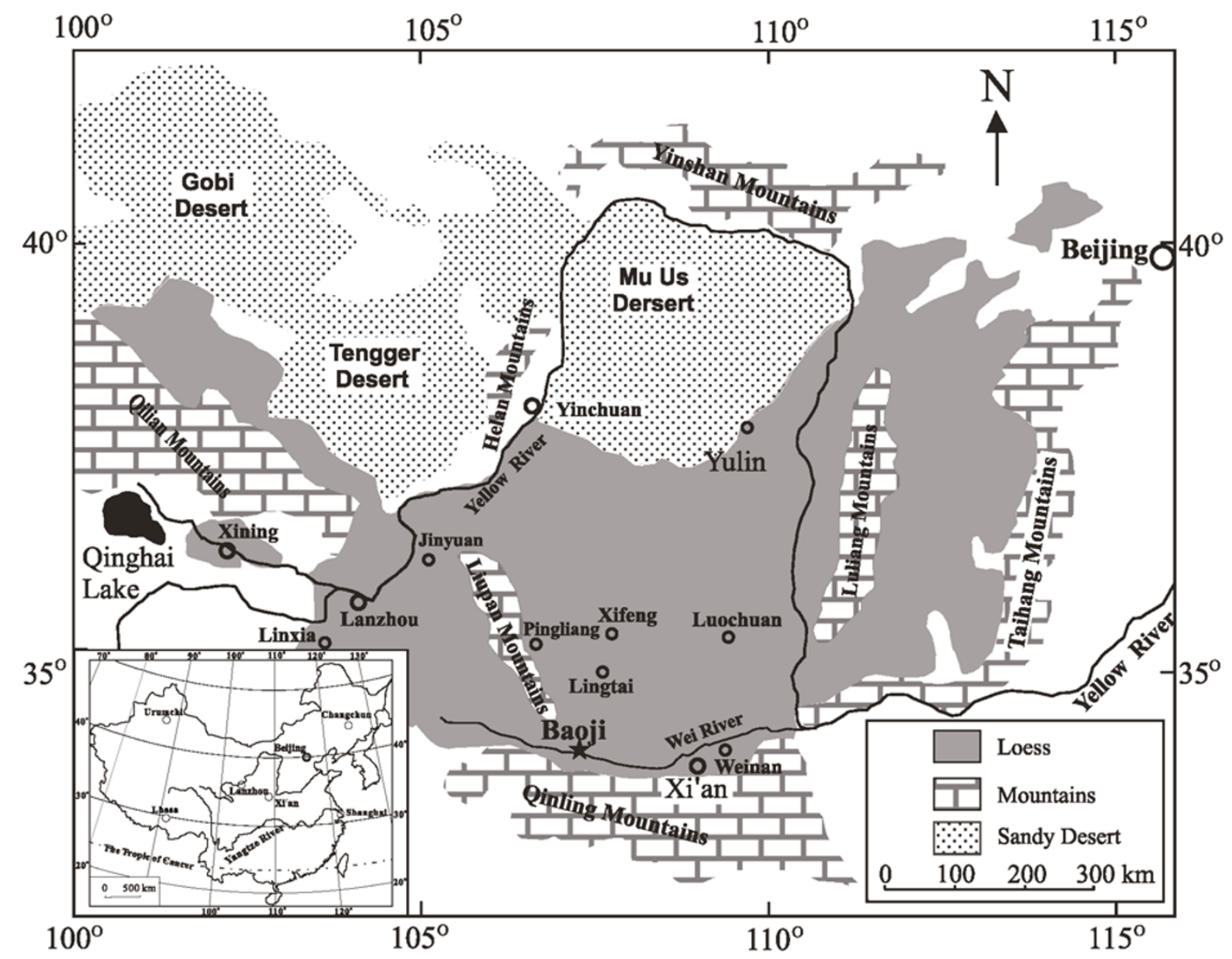

Fig. 1. A sketch map of loess distribution in central China. The Baoji section is marked with a star.

(Liu et al., 1988a), Baoji (Rutter et al., 1990), Lantian (Zheng et al., 1992), Pingliang (Sun et al., 1998), among others. In addition to the major magnetozones, some researchers have focused on shorter geomagnetic polarity changes such as polarity reversals (Rolph et al., 1993; Sun et al., 1993; Zhu et al., 1993, 1994a) and geomagnetic excursions (e.g., Zhu et al., 1994b, 1998, 2006; Fang et al., 1997; Pan et al., 2002; Yang et al., 2004). Although the exact magnetization process of loess is not yet well understood, many short-lived geomagnetic excursions, such as the Mono Lake and Laschamp at loess L1 (Zhu et al., 1999, 2000; Pan et al., 2002), Blake at paleosol S1 (Zhu et al., 1994b; Zheng et al., 1995; Fang et al., 1997; Pan et al., 2002), Santa Rosa at loess L9 (Pan et al., 2002; Yang et al., 2004), and Punaruu at loess L13 (Pan et al., 2002; Yang et al., 2005), have been observed from several different loess sections. Moreover, these excursions can well be correlated with those discovered globally in both volcanic and/or sedimentary paleomagnetic records (e.g., Langereis et al., 1997; Lund et al., 2001; Singer et al., 2002; Oda, 2005). These facts indicate that loess-paleosol deposits have the potential to resolve short-lived excursions as short as a few ka in duration. Furthermore, Heslop et al. (1999) reported a detailed investigation of a 2.25-m section of Late-Glacial sediments at Caoxian in the north-western part of the CLP. The results showed a pattern of relatively smooth oscillations of inclination and declination, which was interpreted as a real geomagnetic signal attributable to the so-called secular variation (SV). Peak-to-peak amplitudes of $20-30^{\circ}$ are consistent with historical observatory records, as are inferred (quasi-)periodicities of a few centuries. Such a palaeo-SV record suggests that at least some loess acquires its remanence within decades, rather than millennia, after deposition.

In this study, we restore a paleomagnetic record from Chinese aeolian sediments near Baoji city to resolve the potential short-lived excursions in the early and middle Matuyama Chrons.

\section{Geological Setting and Paleomagnetic Sam- pling}

The CLP is located in north central China, spreading over an area from the southern edge of the desert near the Great Wall of China in the north to the northern slopes of the Qinling Mountains, and from the Helan mountain in the west to the Taihang mountain in the east (Fig. 1). The Baoji section, which provides an about 160 -m thick loesspaleosol sequence, is located at Linghui village $\left(34.41^{\circ} \mathrm{N}\right.$, $107.13^{\circ} \mathrm{E}$ ), about $5 \mathrm{~km}$ north of Baoji city, Shaanxi province (Fig. 1). This section is considered to be the most complete pedostratigraphic section of the CLP (Rutter et al., 1991), consisting of 37 loess-paleosol layers overlying the Pliocene red clay. A preliminary magnetostratigraphic result was presented by Rutter et al. (1990), and detailed pe- 
dostratigraphic descriptions for each paleosol and loess unit were reported by Rutter et al. (1991). Recent paleomagnetic records with short sampling intervals showed that Baoji loess-paleosol sediments have the potential to resolve shortlived geomagnetic excursions as short as a few ka (Yang et al., 2004).

After removing the superficial weathered layer, orientated block samples were collected at 5- or 20-cm-depth intervals along a well-exposed natural outcrop spanning from $\mathrm{S} 12$ to the top of red clay. In the laboratory, paleomagnetic specimens were further processed from the block samples, and core samples were drilled from calcareous nodule layer in 2004. A total of 1300 specimens were used for paleomagnetic and rock-magnetic measurements, out of which about $25 \%$ specimens, mainly from calcareous nodule layers, have already been presented by Yang et al. (2005).

\section{Laboratory Procedures}

All specimens were thermally demagnetized up to 500 or $600-680^{\circ} \mathrm{C}$ at $30-50^{\circ} \mathrm{C}$ intervals in an ASC-TD48 oven with an internal residual field lower than $10 \mathrm{nT}$. All measurements of natural remanent magnetization (NRM) were made on a 2G-755 magnetometer inside a set of large Helmholtz coils that reduced the ambient geomagnetic field to around $300 \mathrm{nT}$, at the Paleomagnetic Laboratory of the Institute of Geomechanics, Chinese Academy of Geological Sciences. Paleomagnetic data were analyzed using R. Enkin's and J. P. Cogne's computer programs. Characteristic remanent magnetization (ChRM) directions were determined using principal component analysis (Kirschvink, 1980) and Fisher statistics (Fisher, 1953).

For all specimens destined for paleomagnetic measurement, the mass-specific low-field magnetic susceptibility $(\chi)$ was measured using a Bartington MS2B magnetic susceptibility meter. On selected samples, we investigated: (1) the stepwise acquisition of isothermal remanent magnetization (IRM) up to $2.7 \mathrm{~T}$, (2) the three-component IRM thermal demagnetization imparted successively at 2.7, 0.4, and $0.1 \mathrm{~T}$ on the mutually orthogonal sample axes (selected specimens were first imparted a DC field using a 2G-pulse magnetizer, and then measured using a spinner magnetometer), (3) the thermomagnetic analyses with a Curie balance in air and in a magnetic field of $0.6 \mathrm{~T}$, and (4) the anisotropy of low-field magnetic susceptibility (AMS) using a KLY-3S Kappabridge. The rock magnetic analyses were performed at the paleomagnetism laboratories of Kobe and Kochi Universities, Japan, and of Chinese Academy of Geological Sciences.

\section{Results}

\subsection{Susceptibility and NRM behavior}

The results of mass-specific low-field magnetic susceptibility reveal that loess layers, including the calcareous nodules, have a relatively low susceptibility and that paleosol layers have relatively high susceptibility (Fig. 2(b)). The high susceptibility is attributed to the effect of pedogenesis that induces more magnetic enhancement in paseosol than in loess (Zhou et al., 1990). NRM intensities range from 0.51 to $170 \mathrm{~mA} / \mathrm{m}$ with a mean value of $30.3 \mathrm{~mA} / \mathrm{m}$. Figure 2 shows that the susceptibility changes correlated well with the NRM intensity as well as with the lithological variation. This fact suggests both magnetic variations are dominantly controlled by the pedogenesis.

\subsection{Paleomagnetic results}

Representative thermal demagnetization diagrams of normal and reversed polarity specimens shown in Fig. 3 reveal two clear magnetic components. Low-temperature components (LTC) isolated between $100^{\circ} \mathrm{C}$ and $200^{\circ} \mathrm{C}$ are consistent with the present geomagnetic field direction. After removing a LTC, a high-temperature magnetization component (HTC) that decayed toward the origin was isolated between $250^{\circ} \mathrm{C}$ and $620-650^{\circ} \mathrm{C}$ (Fig. 3). ChRM directions were determined using principal component analysis (Kirschvink, 1980) through five points at 300, 350, 400, 450 , and $500^{\circ} \mathrm{C}$. About $95 \%$ of the specimens have either upward inclinations with southerly declinations or downward inclinations with northerly declinations. However, some specimens have ChRM directions that deviate significantly from a geocentric axial dipole field direction (Fig. 4). Some have downward inclinations with declinations that deviate significantly from north (Fig. 4(b), (c), and (1)), and others have upward inclinations with declinations that deviate significantly from south (Fig. 4(h), (j), and (k)) or very shallow inclinations (Fig. 4(b), (e), and (f)). We note that specimens from the fully normal and reverse polarity intervals have firm remanence directions above $300^{\circ} \mathrm{C}$ (Fig. 3), and some from the geomagnetic excursion or polarity transition zones exhibit gradual changes in remanence direction during demagnetization above $300^{\circ} \mathrm{C}$ (equal-area projections of Fig. 4(d), (g), (h), and (i)), implying that their remanence may consist of two components. We were able to isolate a well-defined HTC between $300^{\circ} \mathrm{C}$ and $500^{\circ} \mathrm{C}$ (Fig. 4) but failed to determine another higher temperature component due to too weak intensities. We consider that both HTCs may be the primary magnetizations. Double HTCs may have resulted from a superposition of two different polarities. Another possibility is that samples might have acquired remanence in fields of rapidly changing direction, that is, the high-coercivity components were probably locked in early, followed by locking in of re-aligned middle- and low-coercivity components some time later due to directional change of the geomagnetic field. It is noted that even such specimens with anomalous paleomagnetic directions and demagnetization behaviors have a welldefined LTC that is quite consistent with the present geomagnetic field direction (Fig. 5).

\subsection{Rock-magnetic analyses}

In order to demonstrate that the anomalous magnetization directions and demagnetization behaviors are not due to magnetic mineral alteration, rock magnetic experiments were performed on representative specimens from the excursional and polarity transitional intervals as well as from the surrounding normal and reversed polarity intervals. The results are summarized in Figs. 6, 7, and 8. Acquisition curves of IRM for all specimens show similar characteristics (Fig. 6). They present a quick increase below $200 \mathrm{mT}$, suggesting dominance of low-coercivity phases (magnetite/maghemite). The IRM curves continue to climb slowly and do not fully saturate even at $2.7 \mathrm{~T}$ (Fig. 6), indicating the existence of high-coercivity magnetic frac- 
(a)

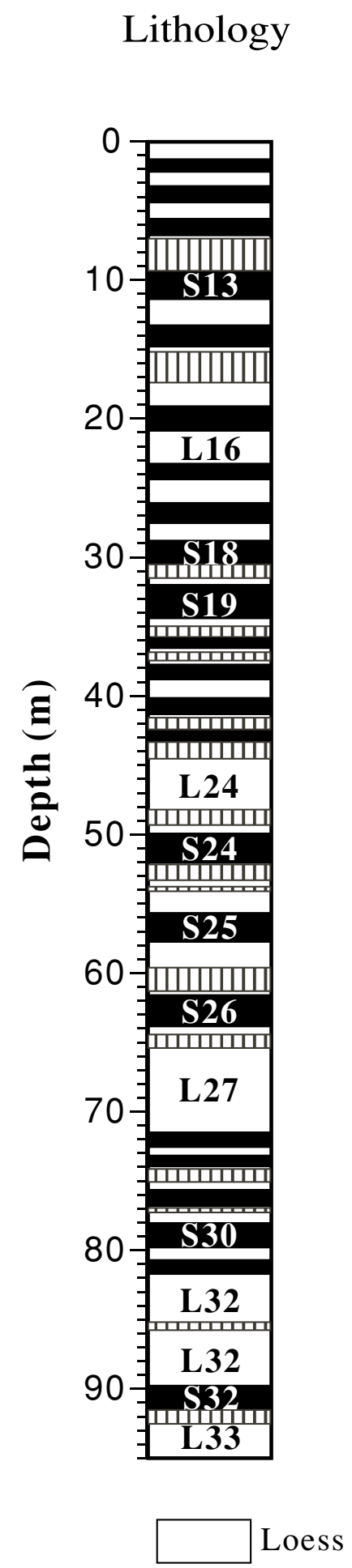

(b) Susceptibility
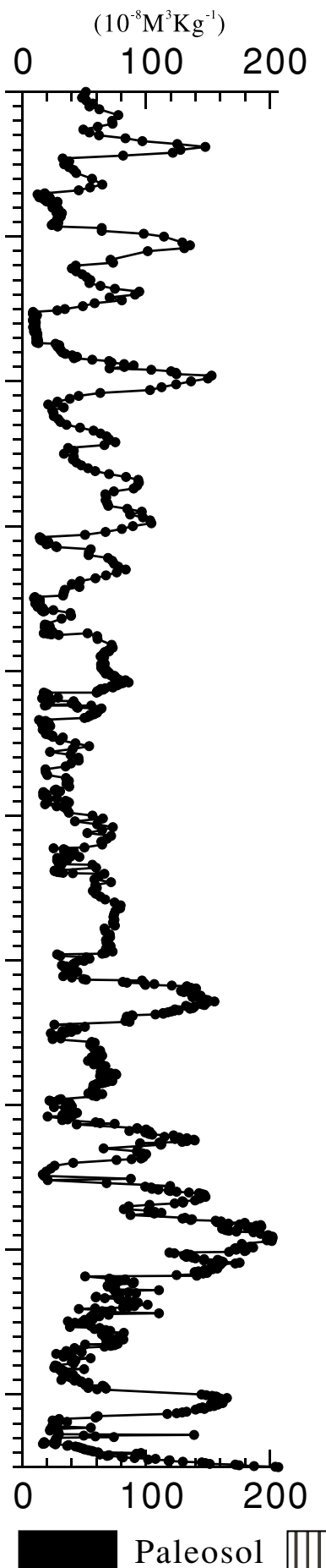

(c)

NRM Intensity

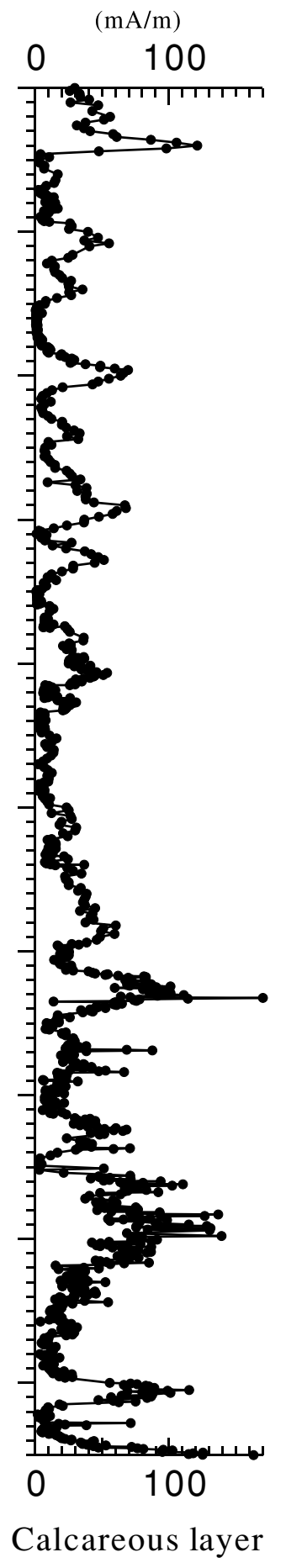

Fig. 2. Lithostratigraphy (a) and stratigraphic variations of mass-specific low-field magnetic susceptibility (b) and NRM intensity (c).

tions. Thermal demagnetization of three-component IRM also shows that all specimens have similar characteristics (Fig. 7), exhibiting strong evidence for low-coercivity magnetite unblocked at $580^{\circ} \mathrm{C}$ and for high-coercivity hematite at $680^{\circ} \mathrm{C}$ (Fig. 7). The medium coercivity $(0.1-0.4 \mathrm{~T})$ fraction also displays distinct inflexions at $300^{\circ} \mathrm{C}$, suggesting that maghemite is probably present (Fig. 7). Furthermore, the thermomagnetic curves also show that all specimens have the same characteristics (Fig. 8), which reveal obvious Curie temperatures of magnetite and hematite and slight thermal decomposition of maghemite. Our rock-magnetic results are well consistent with previous investigations on other loess sections showing that magnetite, hematite, and maghemite are the main magnetic carriers (e.g., Liu et al., 2003). 



Fig. 3. Typical Zijderveld diagrams, normalized intensity decay plots, and equal-area stereographic projections from the fully normal (a, b) and reverse (c, d) polarity intervals. Solid (open) symbols in Zijderveld diagrams represent the projections onto the horizontal (vertical) plane, and solid (open) circles in the stereographic projections indicate positive (negative) inclinations. $\mathrm{J}_{\max }$ stands for the maximum remanence intensity. The stratigraphic level of each sample is indicated.

\subsection{AMS analysis}

AMS results, especially inclinations of the maximum (K1) and minimum (K3) AMS axes, have been widely used to detect possible disturbances of the sediment fabric (e.g., Marino and Ellwood, 1978; Zhu et al., 2006). In order to confirm that paleomagnetic records are not affected by the post-depositional disturbances, the magnetic fabric of most specimens from L22-S22, L27, and L33 was analyzed by means of anisotropy of low-field magnetic susceptibility. The depth plots of the K1 and K3 are shown in Fig. $9(\mathrm{~g})$ and (h), respectively. The AMS results reveal that the inclinations of the $\mathrm{K} 1$ and $\mathrm{K} 3$ are horizontal and vertical, respectively, indicating that the studied sediments still preserve the primary sedimentary fabric. Figure 9(i) shows the depth plots of the degree of anisotropy $(P \equiv \mathrm{K} 1 / \mathrm{K} 3)$. Liu et al. (1988b) found that re-deposited loess has a higher degree of anisotropy $\left(1.032 \leq P \equiv K_{\max } / K_{\min } \leq 1.064\right)$ than original wind-blown deposits $(1.002 \leq P \leq 1.034)$. Our results reveal that all specimens have $P$ values significantly less than 1.032, showing original deposits.

\section{Discussion}

\subsection{Depth plots of magnetic results}

Figure 9 shows that the declinations, inclinations, corresponding VGP latitudes, and maximum angular deviation (MAD) values of the ChRM directions versus strati- graphic depth. The paleomagnetic result clearly defines the lower Jaramillo boundary in the top of L12 $(4.7 \mathrm{~m})$, the Olduvai subchronozone spanning from the middle part of L25 $(53.5 \mathrm{~m})$ to the uppermost part of S26 $(61.65 \mathrm{~m})$, and the Gauss-Matuyama (G-M) boundary at the base of L33 $(93.65 \mathrm{~m})$. Based on the widely accepted definition for the geomagnetic excursions, i.e., the VGP deviates more than $45^{\circ}$ away from its time-averaged position for that epoch (Merrill and McElhinny, 1994; McElhinny and McFadden, 1997), we recognize seven geomagnetic excursions and tentatively name them as the E1 through E7. The E1 (7.6 m) and E2 $(40.15 \mathrm{~m})$ excursions occur in the middle Matuyama chronozone and lie in the L13 and uppermost S22, respectively. The E3 $(60.1 \mathrm{~m})$ excursion occurs within the lower Olduvai subchronozone and in the L26. The E4 $(69.9 \mathrm{~m})$, E5 $(76.8 \mathrm{~m})$, E6 $(82.0 \mathrm{~m})$, and E7 $(85.6 \mathrm{~m})$ excursions occur in the early Matuyama chronozone, which are in the L27, lowermost S29, and upper and middle parts of L32, respectively (Fig. 9). The MAD values of the ChRM directions of most samples are generally less than 10 (Fig. 9(e)), suggesting that the ChRM directions are well-defined. Due to the weaker NRM intensity of the high-temperature fraction, some specimens around the polarity transitions and geomagnetic excursions have larger MAD values, as is often observed in marine sediment cores (e.g., Guyodo et al., 2001; Channell et al., 2002, 2003a; Hyodo et al., 2006). 


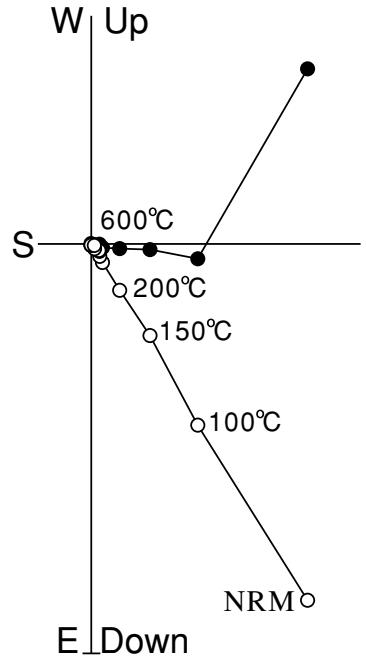

Scale: 1e-2 A/m

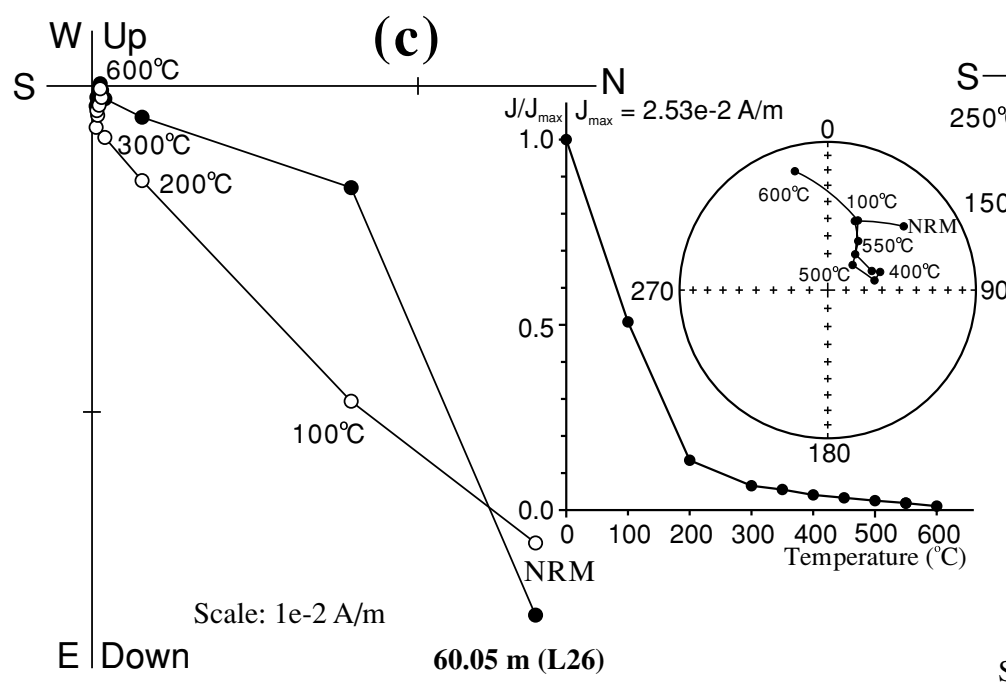

(a)

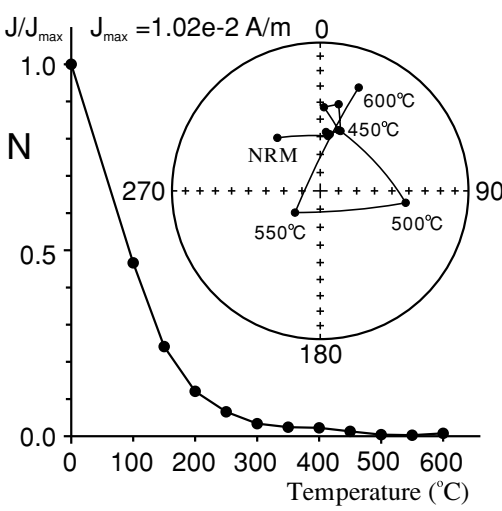

$7.55 \mathrm{~m}(\mathrm{L13})$

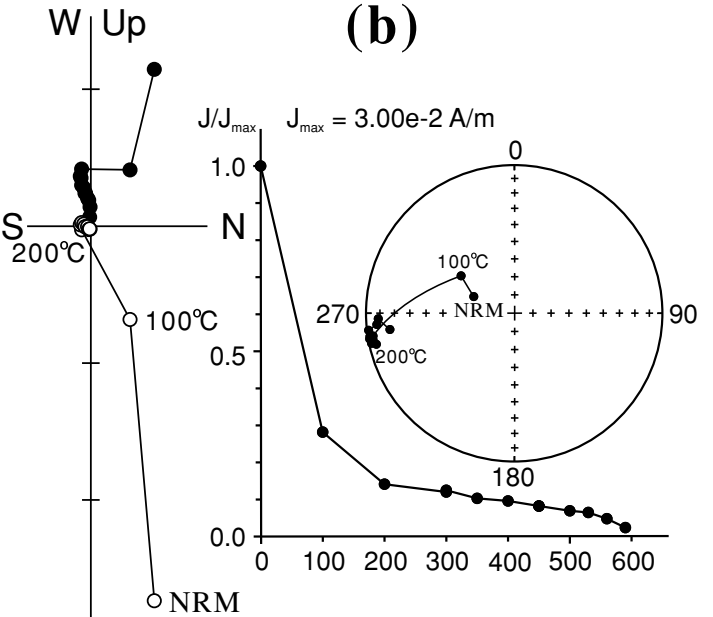

E†Down

Scale: 1e-2 A/m
$40.15 \mathrm{~m}(\mathrm{S22})$

W Up $6650^{\circ} \mathrm{C} N$

(d)

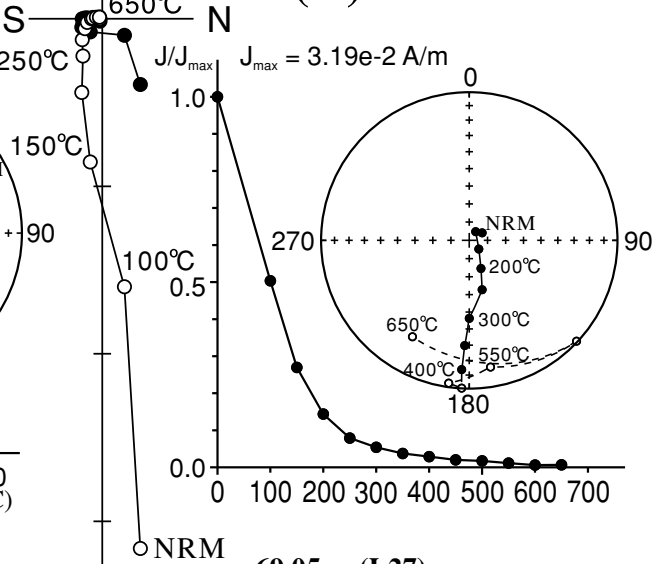

E Down $69.05 \mathrm{~m}(\mathbf{L 2 7})$

Scale: $1 \mathrm{e}-2 \mathrm{~A} / \mathrm{m}$

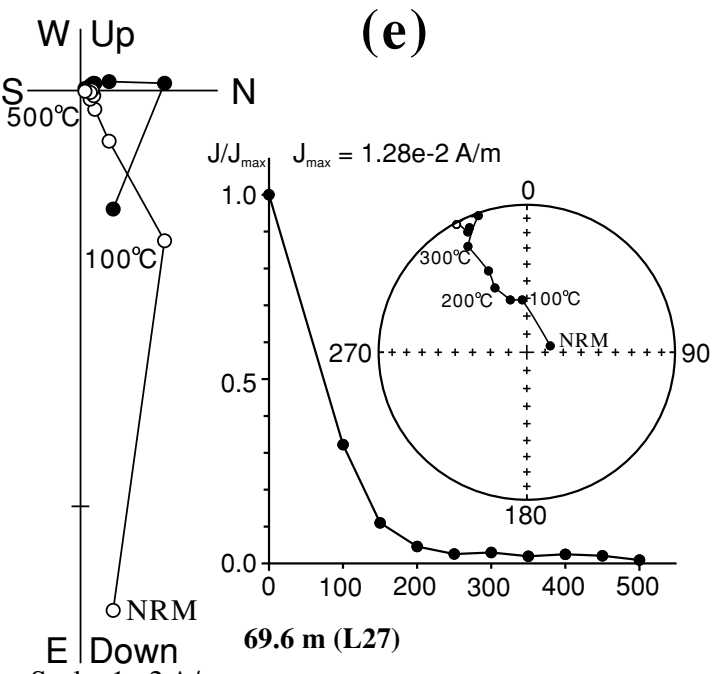

Scale: 1e-2 A/m

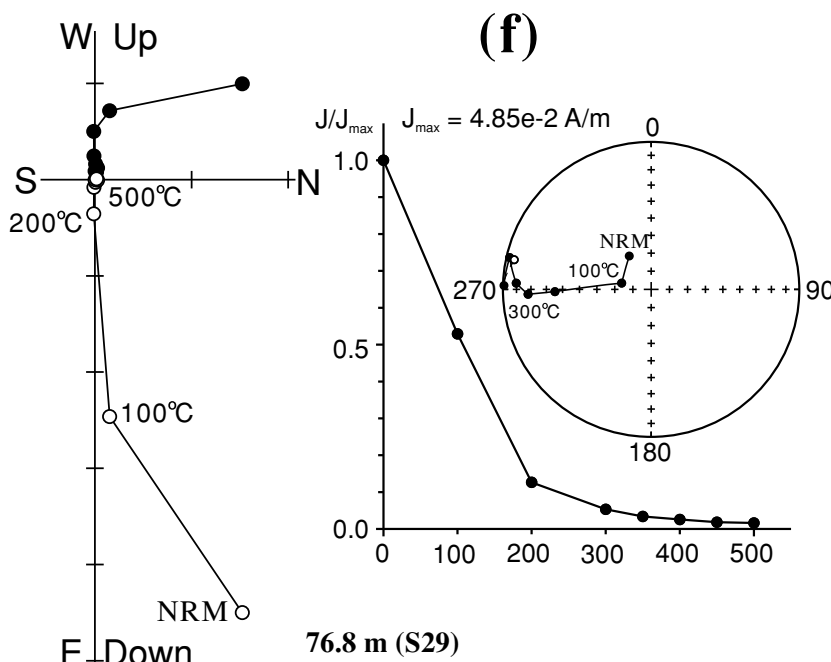

Scale: 1e-2 A/m

Fig. 4. Zijderveld diagrams, normalized intensity decay plots, and equal-area stereographic projections from the excursional intervals (a-h) and the lower Jaramillo (i), Upper Olduvai (j), and G-M (k, l) transitional zones. Solid (open) symbols in the Zijderveld diagrams represent the projections onto the horizontal (vertical) plane, and solid (open) circles in the stereographic projections indicate the positive (negative) inclinations. $\mathrm{J}_{\mathrm{max}}$ stands for the maximum remanence intensity. The stratigraphic level of each sample is indicated. 

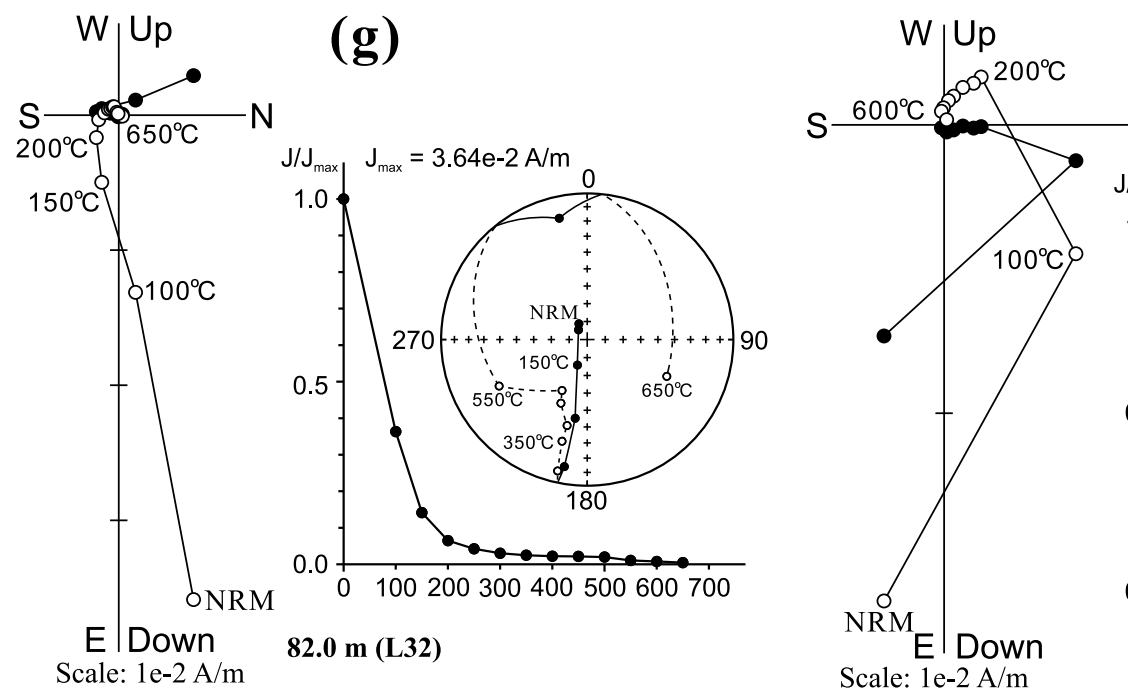

(h)

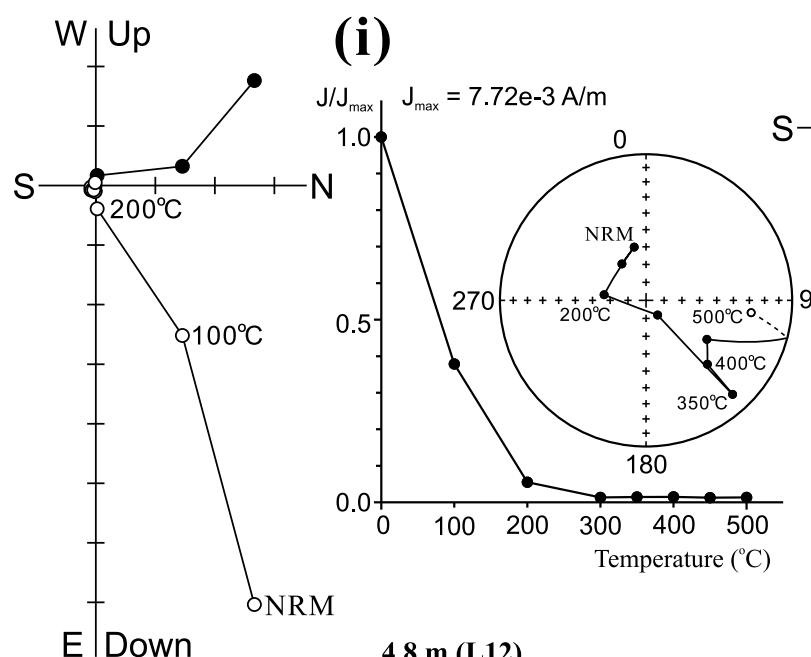

Scale: $1 \mathrm{e}-3 \mathrm{~A} / \mathrm{m}$

$4.8 \mathrm{~m}$ (L12)

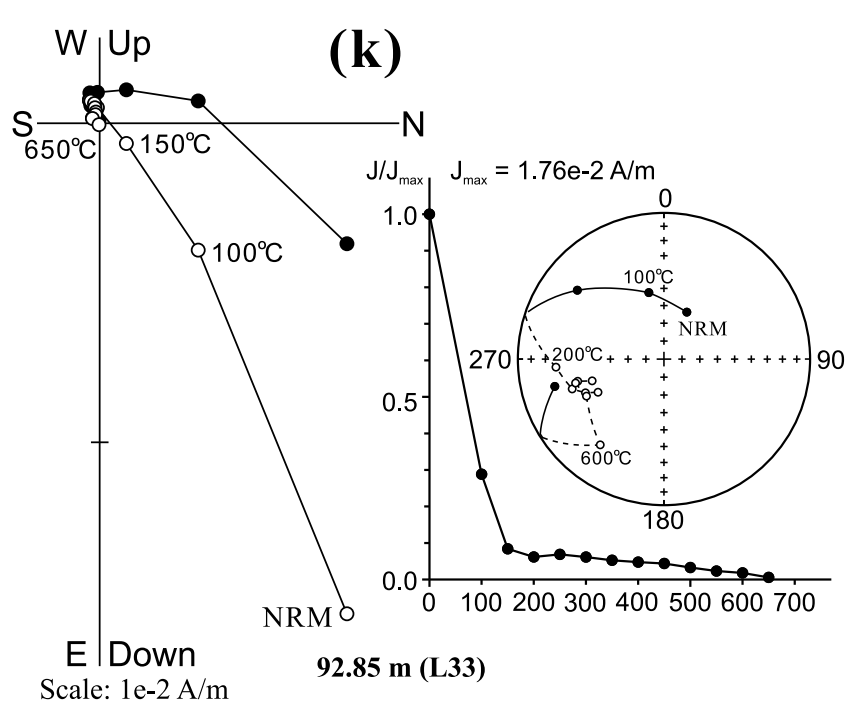

Scale: $1 \mathrm{e}-2 \mathrm{~A} / \mathrm{m}$
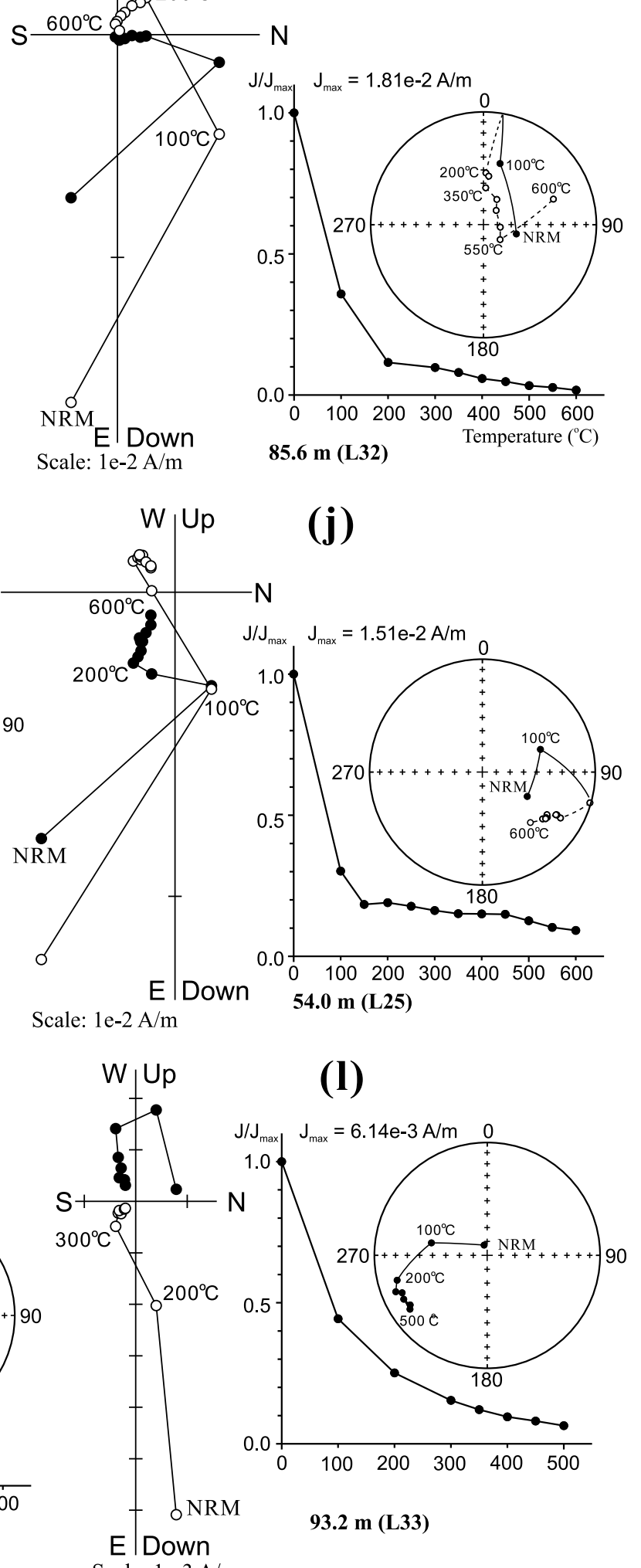

Scale: 1e-3 A/m

Fig. 4 (continued). 


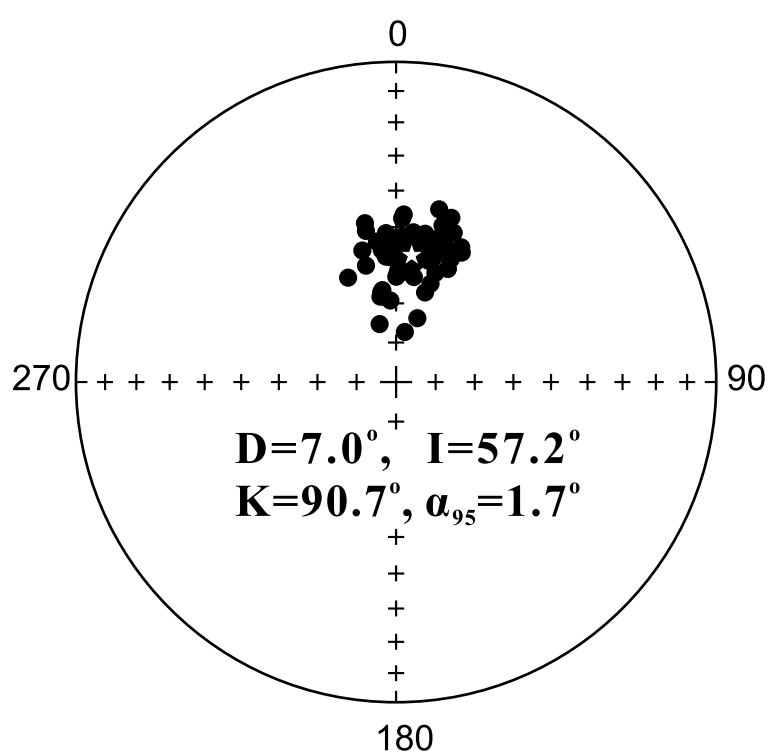

Fig. 5. Equal-area projection of the LTCs from the excursional and polarity-transition intervals. The star indicates the overall mean direction of 61 specimens.

Channell et al. (2003a) attributed this result to superposition of normal and reverse magnetization directions. The rock-magnetic experiments mentioned above reveal that the specimens from the excursional and polarity transitional intervals have the same magnetic characteristics as those from the surrounding normal and reversed polarity intervals. AMS results show that the studied loess-paleosol sediments still preserve the primary sedimentary fabric. These results together with the well-defined LTCs that are consistent with the present geomagnetic field direction (Fig. 5) support the conclusion that these anomalous paleomagnetic directions do not result from magnetic mineral alteration and/or sedimentological disturbance, but record excursions. The many anomalous directions that lie around polarity transitions suggest that they probably reflect fluctuations of the geomagnetic field.

\subsection{Stratigraphic position of the lower Olduvai bound- ary}

Through sampling at close intervals (ca. $5 \mathrm{~cm}$ in level) and the better determined ChRM directions, Fig. 8 of Yang et al. (2005) shows that the lower Olduvai boundary lies at the top of S26. However, they did not mention this in their publication. Our magnetostratigraphic result slightly disagrees with the previous one from the Baoji section by Rutter et al. (1990). Figure 4 of Rutter et al. (1990) shows that a possible excursion below the Olduvai subchron was interpreted as the lower Olduvai transition. On the other hand, Fig. 5 of Rutter et al. (1990) shows that the lower Olduvai boundary is at the upper part of L27, which does not correspond to E4 (Fig. 9). With the exception of these differences, these two magnetostratigraphic results well agree with each other.

\subsection{Age estimates of the geomagnetic excursions}

Magnetic susceptibility (and/or grain size) variations of Chinese loess-paleosol sequences are often correlated with marine oxygen isotope $\left(\delta^{18} \mathrm{O}\right)$ records (e.g., Heller and Liu, 1984; Liu, 1985; Kukla, 1987). Based on such cli-
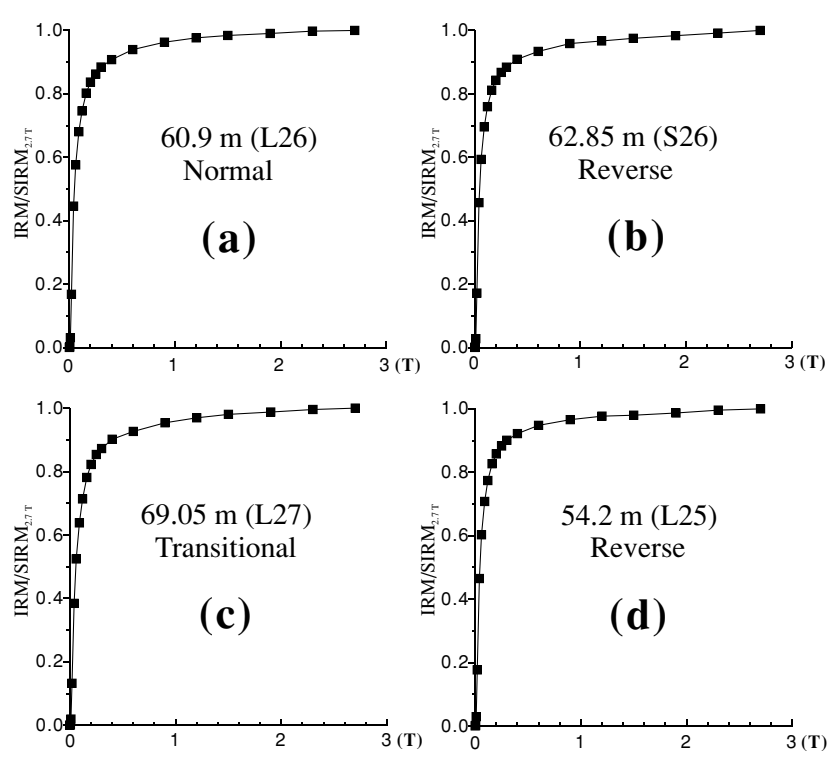

Fig. 6. Normalized IRM acquisition curves of the representative specimens from the normal (a), reverse (b), excursional (c), and polarity-transition (d) intervals. The sample in (b) is from paleosol, and the others are from loesses.
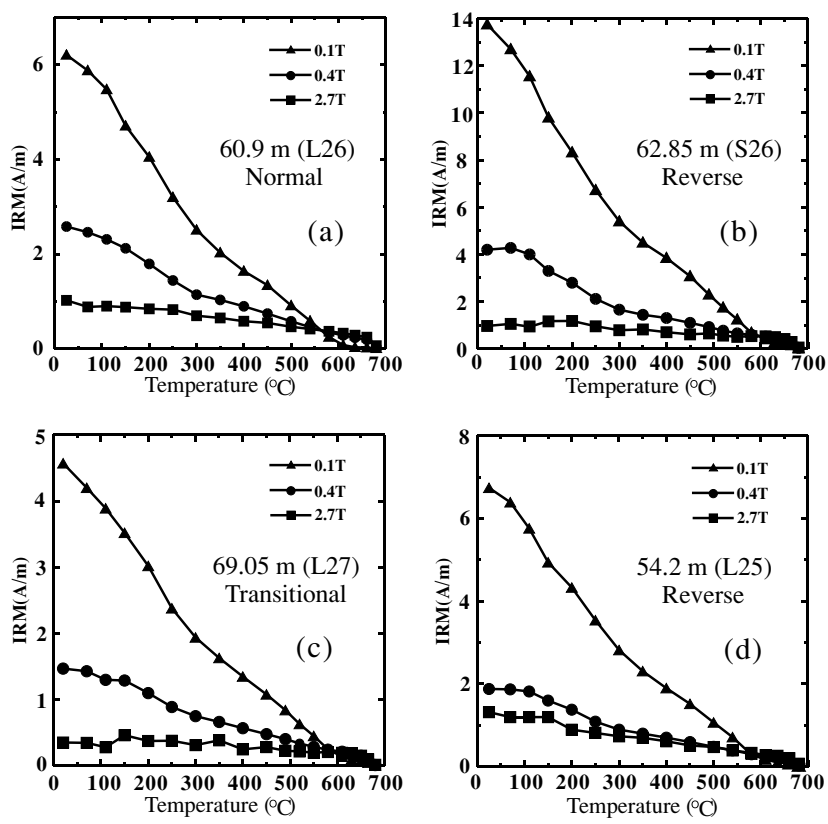

Fig. 7. Three-component IRM thermal demagnetization of the representative specimens from the normal (a), reverse (b), excursional (c), and polarity-transition (d) intervals. The sample in (b) is from paleosol; the others are from loesses.

matological correlations, several astronomical timescales have been proposed (e.g., Heslop et al., 2000; Ding et al., 2002; Sun et al., 2006). However, it should be noted that the Chinese loess-paleosol records are well correlated with the $\delta^{18} \mathrm{O}$ record during the Brunhes Chron, whereas older loess-paleosol sequences, especially the early Pleistocene Wucheng loess-paleosol ones, can not easily be correlated with it because they show quite different climatic fluctuations. Consequently, the same loess or paleosol unit deposited in the Matuyama Chron was often correlated to different marine oxygen isotope stage (MIS) numbers, leading 

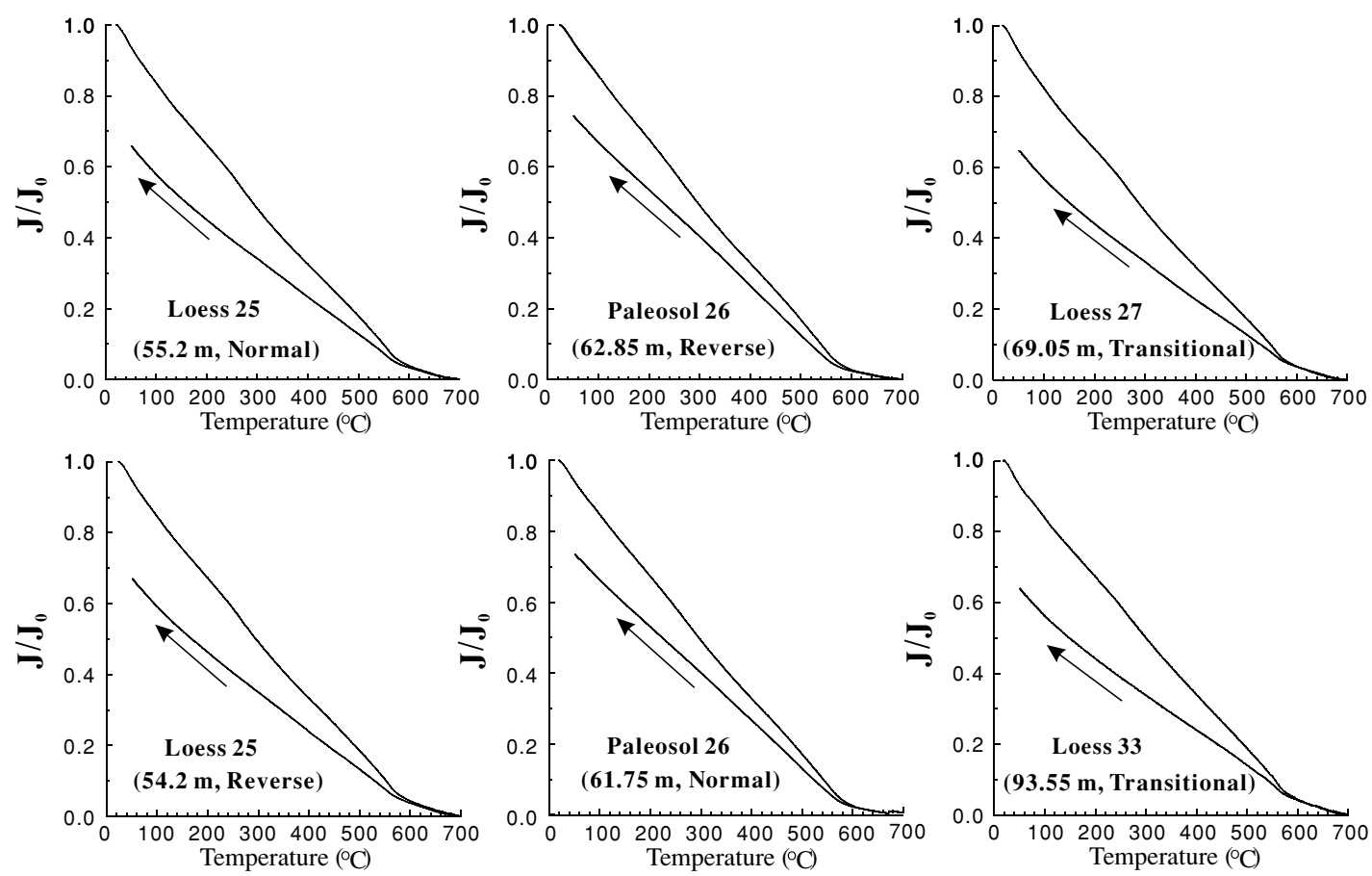

Fig. 8. Thermomagnetic curves obtained in air atmosphere and in a magnetic field of 0.6 T. Specimens in (a), (b), and (c) are from the normal, reverse, excursional intervals, respectively, and those in (d), (e), and (f) are from the upper Olduvai, lower olduvai, and G-M transitional zones. The level and polarity of each sample are indicated.

to constructions of different timescales. For example, Heslop et al. (2000) correlated the L13 with the MIS 32-34 and assigned an age range of 1.080-1.162 Ma, whereas Ding et al. (2002) and Sun et al. (2006) correlated it to the MIS 34 and gave an age ranging from 1.120 to $1.158 \mathrm{Ma}$. For the S26, Heslop et al. (2000) and Ding et al. (2002) assigned it to MIS 69-71 and 1.89-1.95 Ma, while Sun et al. (2006) correlated it to MIS 71-73 and 1.91-1.95 Ma. Thus, for the Matuyama loess-paleosol units there is no widely accepted timescale based on climatological correlations. In addition, the loess unit L8, where the Matuyama-Brunhes (M-B) boundary was often observed to occur, is correlated with MIS 20 in the above astronomical timescales (Heslop et al., 2000; Ding et al., 2002; Sun et al., 2006). As a result, the M-B boundary is dated from 801 ka for the Baoji section to $816 \mathrm{ka}$ for the Lingtai section (see Sun et al., 2006), and these ages are 21-36 ka older than the generally accepted age (Cande and Kent, 1995). A delayed lock-in of paleomagnetic signals in the loess-paleosol sequence was proposed to explain the discrepancy of the M-B boundary (Zhou and Shackleton, 1999; Heslop et al., 2000; Spassov et al., 2003). In contrast, Wang et al. (2006) considered that the estimated M-B boundary age biased toward the older age in the loess-paleosol record might not result from lockin effects associated with pedogensis, but from incorrect climatological correlations. Considering that the previously reported astronomical timescales and climatological correlations are not in agreement even in this study, we estimate the ages of the geomagnetic excursions by interpolating a constant accumulation rate between polarity boundary ages.

Assuming a constant accumulation rate between polarity boundaries (Cande and Kent, 1995), these middle and early Matuyama excursions are dated at about $1.11 \mathrm{Ma}(\mathrm{E} 1)$,
1.58 Ma (E2), 1.92 Ma (E3), 2.11 Ma (E4), 2.25 Ma (E5), 2.35 Ma (E6), and 2.42 Ma (E7), respectively (Table 1).

\subsection{Geomagnetic excursions in the middle Matuyama Chron}

5.4.1 Punaruu excursion (E1) The E1 excursion in the upper L13 (Fig. 9), which includes transitional and fully normal-polarity directions (Fig. 4(a)), is estimated to be 1.11 Ma. Pan et al. (2002) also found a geomagnetic excursion in the upper L13 of the Weinan section about 250 $\mathrm{km}$ east of Baoji and estimated an age of $1125 \mathrm{ka}$ based on an astronomical timescale proposed by Heslop et al. (2000). This stratigraphic agreement of their occurrences indicates that they represent the same excursion. This E1 excursion is chronologically well correlated with the Punaruu excursion dated at $1.105 \pm 0.005 \mathrm{Ma}$ by the ${ }^{40} \mathrm{Ar} /{ }^{39} \mathrm{Ar}$ methods (Singer et al., 1999) (Fig. 10). Chauvin et al. (1990) first found the transitionally magnetized lavas in Punaruu Valley and interpreted the transitional directions to record a field behavior during the Cobb Mountain subchron (CM). Singer et al. (1999) further investigated these transitionally magnetized lavas in Punaruu Valley. Since the weighted mean age for these lavas is significantly younger than that for the CM, they concluded that the transitional directions recorded a geomagnetic excursion which occurred at about $76 \mathrm{ka}$ after the CM, and designated this as the Punaruu excursion. Subsequently, the Punaruu excursion was further observed from marine sediments at Ocean Drilling Program Sites 983 and 984 in the Iceland Basin and dated at $1115 \mathrm{ka}$ (Channell et al., 2002).

5.4.2 CM subchron The CM at 1.20-1.21 Ma (Cande and Kent, 1995) is a well-established short-polarity subchron and has been observed globally (e.g., Clement and Kent, 1987; Biswas et al., 1999; Yang et al., 2001; Chan- 




Fig. 9. Summary of magnetic results at the Baoji section. (a) Lithology, (b) declination and (c) inclination of the ChRM, (d) virtual geomagnetic pole (VGP) latitude, (e) maximum angular deviation (MAD) values, (f) magnetic polarity, (g) K1-Inc, (h) K3-Inc, and (i) the degree of AMS. The data with open circles have already been reported by Yang et al. (2005).

nell et al., 2002; Horng et al., 2002; Yamazaki and Oda, 2005). Magnetostratigraphies in the CLP have already revealed the presence of the CM subchron (Zheng et al., 1992; Li et al., 1997). At the Lantian section near Xi'an city, Zheng et al. (1992) found a short geomagnetic excursion within the upper part of the second sandy horizon L15 and regarded it as the CM event. Liu et al. (1988a) recognized a normal sub-zone in the upper of the second layer L15. This normal interval involves 11 successive sampling horizons and covers a 2.2-m thickness of the stratigraphy, so it may also represent the CM subchron. Li et al. (1997) identified the CM subchron within the bottom of loess L15 and estimated it at $1.177 \mathrm{Ma}$ by assuming a constant accumulation rate between the lower Jaramillo and M-B boundaries and extrapolating this rate downward. At the Pingliang section, we note the presence of the possible normal polarity direction within the loess L15, but Sun et al. (1998) provided no explanation for it. At the Weinan section, Guo et al. (1998) documented a normal polarity interval within loess L13 and correlated it with the CM subchron. Pan et al. (2002) re-studied the Weinan section and regarded the normal polarity interval in the L13 as the Punaruu excursion. Even by the high-resolution (5- to $10-\mathrm{cm}$ intervals) record from the studied section, we do not observe a nor- 
Table 1. Age estimates of the geomagnetic excursions assuming a constant accumulation rate between polarity boundaries. The polarity ages are after Cande and Kent (1995).

\begin{tabular}{cccc}
\hline $\begin{array}{c}\text { Excursions } \\
\text { Ploarity boundaries }\end{array}$ & $\begin{array}{c}\text { Mid-depth } \\
(\mathrm{m})\end{array}$ & $\begin{array}{c}\text { Stratigraphic } \\
\text { positions }\end{array}$ & $\begin{array}{c}\text { Model age } \\
(\mathrm{Ma})\end{array}$ \\
\hline Lower Jaramillo & $\mathbf{4 . 7}$ & $\mathbf{L 1 2}$ & $\mathbf{1 . 0 7}$ \\
E1 & 7.6 & L13 & 1.11 \\
E2 & 40.15 & S22 & 1.58 \\
Upper Olduvai & $\mathbf{5 3 . 5}$ & L25 & $\mathbf{1 . 7 7}$ \\
E3 & 60.1 & L26 & 1.92 \\
Lower Olduvai & $\mathbf{6 1 . 6 5}$ & $\mathbf{S 2 6}$ & $\mathbf{1 . 9 5}$ \\
E4 & 69.9 & L27 & 2.11 \\
E5 & 76.8 & S29 & 2.25 \\
E6 & 82.0 & L32 & 2.35 \\
E7 & 85.6 & L32 & 2.42 \\
G-M & $\mathbf{9 3 . 6 5}$ & L33 & $\mathbf{2 . 5 8}$ \\
\hline
\end{tabular}

mal polarity or even an excursional direction from the S14 to the L15. Both the CM and Punaruu excursion have been found in the same marine core record (Guyodo et al., 2001; Channell et al., 2002). The absence of the CM at the Baoji section as well as at other loess sections (e.g., Luochan) implies that short post-depositional erosions-or no deposits at all-might have occurred in part of the CLP, as suggested by an earlier investigation (e.g., Rutter et al., 1991).

5.4.3 Stage 54 (or Gilsa) excursion (E2) The E2 excursion occurs in the uppermost part of S22 (Fig. 9) and is clearly characterized by a westerly declination $\left(259.8^{\circ}\right)$ and a low inclination $\left(-0.7^{\circ}\right)$ (Fig. $4(\mathrm{~b})$ ). The excursion is estimated at $1.58 \mathrm{Ma}$ (Table 1) and may be correlated with the "Stage 54" event (Fig. 10) that was originally found in a deep-sea core in the North Atlantic and regarded as the Gilsa subchron (Clement and Kent, 1987). McDougall and Wensink (1966) first recognized the Gilsa event from lava in Iceland and estimated it at $1.60 \mathrm{Ma}$ by K-Ar dating. Watkins et al. (1975) re-studied the section in Iceland and dated the normal polarity lava at $1.58 \mathrm{Ma}$. Udagawa et al. (1999) further confirmed the existence of the Gilsa event in lavas of Eastern Iceland and estimated it to occur at about 1.60 Ma. Channell et al. (2002) documented a normal polarity interval at the MIS 54 of Ocean Drilling Program Sites 983 and 984 (Iceland Basin). By correlating its boundaries to the MIS, they dated it at $1.567-1.575 \mathrm{Ma}$ and further correlated it with the Gilsa subchron. Because the Gilsa event was recorded in the MIS 54, Zijderveld et al. (1991) proposed replacing it by the "Stage 54" event. On the basis of the MIS number (e.g., Horng et al., 2002), the "Stage 54" event is estimated to occur at about $1.58 \mathrm{Ma}$, which is consistent with our estimated age (1.58 Ma) for the E2 excursion. Li et al. (1997) also documented a geomagnetic excursion at paleosol S22 of loess sequences that overlie fluviatile sediments on seven terraces of the Yellow River in the Linxia Basin. Assuming a constant accumulation rate between the lower Jaramillo and M-B boundaries and extrapolating this rate downward, Li et al. (1997) dated this excursion at 1.537-1.551 Ma and further correlated it to the "Stage 54" event. Biswas et al. (1999) also recognized a middle Matuyama event from the 1700-m Osaka Bay core. Based on a constant accumulation rate of $61 \mathrm{~cm} / \mathrm{ka}$ between the upper Olduvai boundary and CM, this event was estimated at 160-1.62 Ma. Biswas et al. (1999) correlated it with the "Stage 54" event.

Another possible correlation for the E2 excursion is the Sangiran excursion documented from the Pucangan Formation in Java, which has well been duplicated from the Plio-Pleistocene sediments in Sangiran and Mojokerto and is characterized by declinations having a maximum westerly deflection of more than $70^{\circ}$ from the axial dipole direction and inclinations that always remain low (Hyodo et al., 1992). Another characteristic of the Sangiran excursion is its long-term persistence. Assuming a constant accumulation rate between the Jaramillo and Olduvai subchronozones of the geomagnetic polarity timescale (GPTS) of Cande and Kent (1995), Biswas et al. (1999) re-estimated its age range from 1.50 to $1.62 \mathrm{Ma}$. Consequently, the E2 excursion in the present study may only record one stage of the Sangiran excursion. The worldwide observation of the excursions dated at a similar age suggests that the E2 excursion may represent a global occurrence.

5.5 A possible early Olduvai excursion at $1.92 \mathrm{Ma} \mathrm{(E3)}$

The E3 excursion is characterized by the easterly declination deflecting more than $90^{\circ}$ from the axial dipole field direction (Fig. 4(c)). This excursion is dated at $1.92 \mathrm{Ma}$ (Тable 1) and occurs just about $30 \mathrm{ka}$ after the lower Olduvai reversal. Although such a short-lived geomagnetic excursion has not been well-recognized, Sun et al. (1998) documented the existence of anomalous geomagnetic field directions within the lower part of the Olduvai subchronzone from the Pingliang loess section - to which they gave no interpretation. Assuming a constant accumulation rate within the whole Olduvai subchron, this reversed polarity direction is estimated at about $1.92 \mathrm{Ma}$, which is well consistent with the estimated age for the E3 excursion. In addition, Biswas et al. (1999) also confirmed an anomalous paleomagnetic direction in the lower part of the Olduvai subchronzone in the Osaka Bay core (Fig. 10). However, they also provided no interpretation to it. The anomalous field directions are all from the lower part of the Olduvai subchronzone and observed in different sediments in China and Japan. These facts suggest the possible existence of an early Olduvai excursion in East Asia, but further studies are necessary to support its global occurrence.

\subsection{Geomagnetic excursions in the early Matuyama Chron}

5.6.1 Réunion II and Réunion I subchrons (E4 and E5) Four geomagnetic excursions are recognized in the early Matuyama Chron (Fig. 9). The E4 excursion in the L27 is defined by more than ten excursional specimens (Fig. 4(d) and (e)) and estimated at 2.11 Ma with a duration of about $20 \mathrm{ka}$ (Table 1). This excursion can be correlated to the Réunion II (C2r.1n in the GPTS of Cande and Kent (1995)). The Réunion subchron was originally found in the island of La Réunion and includes both normal and reverse magnetizations in basaltic rocks yielding K-Ar ages close to 2.0 Ma (Chamalaun and McDougall, 1966). The normal polarity directions were, at that time, considered to be coeval with those from the Olduvai Gorge documented by Gromme and Hay (1971). McDougall and Watkins (1973) also documented the normal polarity Réunion event from 


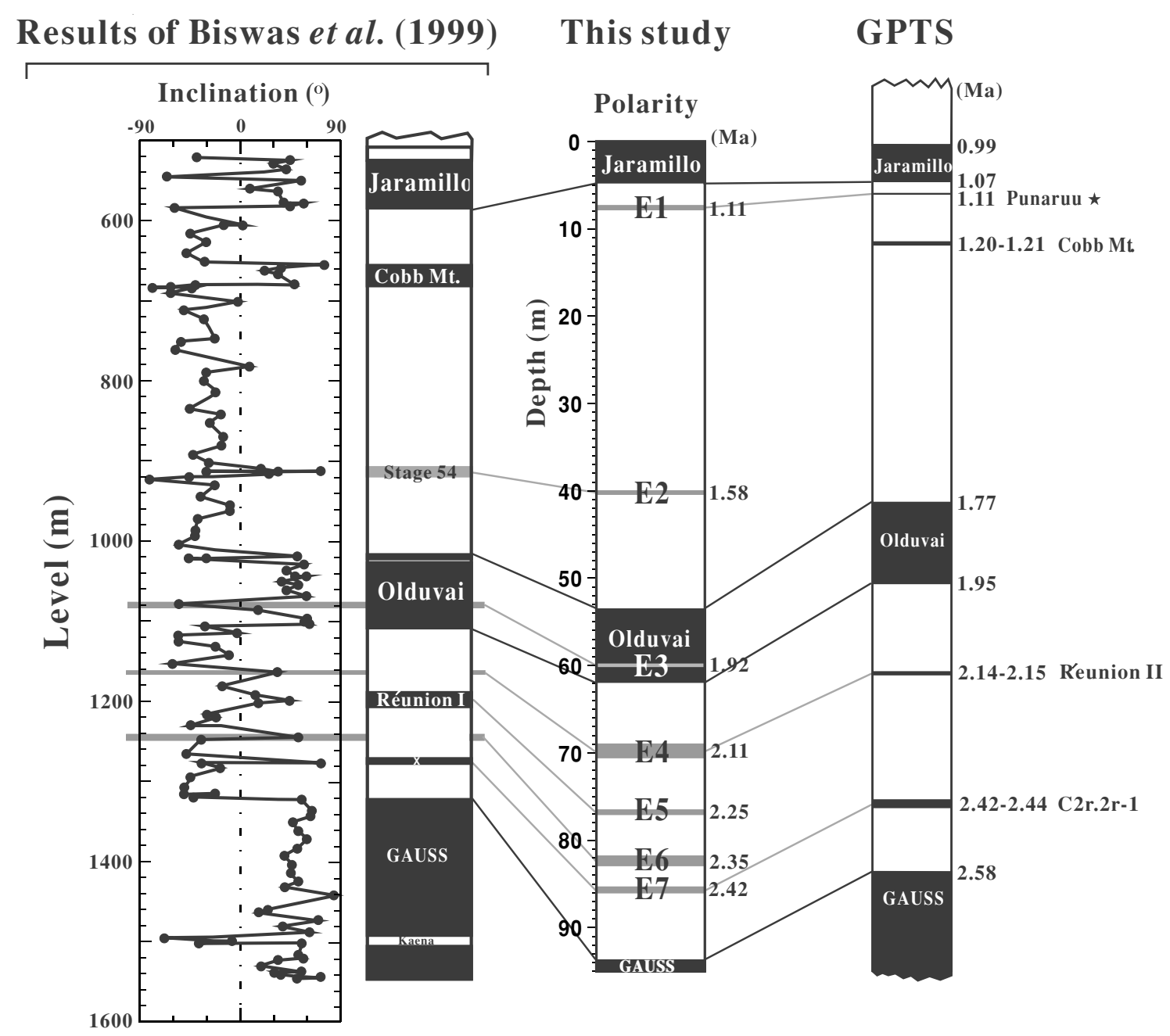

Fig. 10. Correlation of magnetostratigraphic results of the early and middle Matuyama Chron from the Baoji loess-paleosol sediments with those from the Osaka Bay core sediments (Biswas et al., 1999), and the GPTS of Cande and Kent (1995). The Punaruu excursion marked with a star in the GPTS is after Singer et al. (2002).

olivine basalt lavas of Réunion. Using the K-Ar method, they dated the Réunion event to have a mean age of 2.02 $\mathrm{Ma}$, corresponding to $2.07 \mathrm{Ma}$ using the more modern decay constants recommended by Steiger and Jager (1977), thus concluding that it clearly is older than the Olduvai event. Kidane et al. (1999) identified a normal polarity interval that was correlated to the Réunion subchron, from lava flows in Ethiopian Afar, and obtained a mean K-Ar age of $2.07 \mathrm{Ma}$ that was recalculated by Baksi and Hoffman (2000) as 2.05 Ma. In addition, they regarded an earlier episode of large secular variation below the normal polarity interval as a second Réunion subchron. It is noted that the Réunion (II) subchron has also been observed from many sedimentary paleomagnetic records. At DSDP Site 609, the Réunion subchron was recognized in Holes 609, 609B, and 609C (Clement and Kent, 1987), correlated to MIS 79-81 (Raymo et al., 1989). Zijderveld et al. (1991) documented a normal polarity zone at a level corresponding to MIS 81 and considered it to represent the Réunion subchron. In the Seneze maar of France, Roger et al. (2000) recognized a tephra layer interbedded in the sediments contemporaneous with the Réunion event and calculated the ${ }^{40} \mathrm{Ar} /{ }^{39} \mathrm{Ar}$ age of 2.10 Ma, which was further recalculated by Baksi (2001) as
2.14 Ma. Horng et al. (2002) observed a possible record of a double Réunion event during the age interval of 2.1182.133 Ma (Réunion II) and below the MIS 81 (Réunion I). Channell et al. (2003b) reported a high-resolution magnetic record at ODP Site 981 in the North Atlantic where the Réunion subchronozone spans from the MIS 81/82 boundary to the MIS 79, corresponding to the 2.153-2.115 Ma interval. Yamazaki and Oda (2005) documented the Réunion subchron from the equatorial Pacific sediment core where it occurred at the MISs 81-82. Numerous observations of the Réunion (II) subchron show that it is an undoubtedly global occurrence.

The E5 excursion in the S29 is defined by only one specimen (Fig. 4(f)) and estimated at 2.25 Ma (Table 1). This excursion can be correlated with the Réunion I. Although it is still not well reconciled to the polarity structure of the Réunion subchron (i.e., single or double event), some studies showed a double Réunion subchron. In a compilation of the GPTS for the last $5 \mathrm{Ma}$, Mankinen and Dalrymple (1979) adopted the two Réunion events proposed by Gromme and Hay (1971) and estimated their ages as 2.012.04 Ma and 2.12-2.14 Ma, respectively. In a re-calibration of the Pliocene and early Pleistocene GPTS using the K-Ar 
dated fluvial sequence of the Turkana Basin in East Africa, McDougall et al. (1992) reported new ages for the Réunion II at 2.11-2.15 Ma and the Réunion I at 2.19-2.27 Ma; these agree with our estimated ages for the E4 at $2.11 \mathrm{Ma}$ (with a duration of about $20 \mathrm{ka}$ ) and the E5 at $2.25 \mathrm{Ma}$ (Table 1).

Previous magnetostratigraphies in the CLP have also revealed the presence of the Réunion subchron (Liu et al., 1988a; Zheng et al., 1992; Sun et al., 1998). At the Pingliang section, Sun et al. (1998) found a single Réunion event at the depth of 137-138 m. Assuming a constant accumulation rate between the G-M (129.2 m) and lower Olduvai $(166.5 \mathrm{~m})$ boundaries, the single Réunion event is estimated at $2.09 \mathrm{Ma}$, with a duration $17 \mathrm{ka}$, which is consistent with the estimated age (2.11 Ma, with a duration about $20 \mathrm{ka}$ ) of the E4 excursion. At the Lantian section, Zheng et al. (1992) identified two normal polarity intervals within the early Matuyama Chron and correlated these with the Réunion I and Réunion II events, respectively. Assuming a constant accumulation rate between the M-B $(50.5 \mathrm{~m})$ and G-M (133.5 m) boundaries, we estimate the upper (113.5 $\mathrm{m})$ and lower $(118.5 \mathrm{~m})$ normal polarity intervals at about 2.15 Ma and 2.25 Ma, respectively, which corresponds to our estimated ages for the E4 (2.11 Ma) and E5 (2.25 Ma) excursions. At the Xifeng section, Liu et al. (1988a) also documented two normal polarity intervals within the early Matuyama Chron; they interpreted the upper one as the Réunion (II) subchron but gave no interpretation for the lower one that might record a second Réunion (I) subchron. In addition, a doubled Réunion subchron was also confirmed from the Osaka Bay sediments, Japan (Biswas et al., 1999). A short normal-polarity zone from 1191.7 to $1200.7 \mathrm{~m}$ underlying the Olduvai subchronozone is defined by three successive data points. Assuming a constant accumulation rate between the G-M and lower Olduvai boundaries, Biswas et al. (1999) estimated its age at 2.20-2.23 Ma and correlated it with the Réunion I. Biswas et al. (1999) also recognized a normal-polarity horizon $(1162.15 \mathrm{~m})$ that was dated at $2.12 \mathrm{Ma}$ and correlated it with the Réunion II subchron. Considering that the double Réunion subchron is not well established to date, more high-resolution paleomagnetic records are still necessary to clarify its detailed polarity structure in the future.

5.6.2 A possible excursion at 2.35 Ma (E6) The E6 excursion is defined by two specimens (Fig. 4(g)) and dated at 2.35 Ma (Table 1). At present, the E6 excursion has not been correlated with the reported one in the early Matuyama Chron. However, we note the presence of a normal-polarity horizon at $1248 \mathrm{~m}$ of the Osaka Bay sediments (Fig. 10) that Biswas et al. (1999) gave no interpretation to. Assuming a constant accumulation rate between the G-M and lower Olduvai boundaries, the normal-polarity horizon is dated at about $2.37 \mathrm{Ma}$, so it can be chronologically correlated with the E6 excursion (Fig. 10).

5.6.3 Cryptochron C2r.2r-1 or X-subchron (E7) The E7 excursion occurs in the middle part of L32 (Fig. 9) and is defined by two excursional specimens that have clear northerly declinations $\left(357.5^{\circ}\right.$ and $\left.1.3^{\circ}\right)$ and upward inclinations $\left(-39.8^{\circ}\right.$ and $\left.-22^{\circ}\right)$ (Fig. 4(h)). Our age model gives an age of $2.42 \mathrm{Ma}$ to the E7 excursion (Table 1), chronologically well correlated with the X-subchron or the cryptochron C2r.2r-1 that has been dated by Cande and Kent (1995) to occur at 2.42-2.44 Ma (Fig. 10). Based on seafloor spreading profiles, Cande and Kent (1992) described two magnetic anomalies between seafloor anomalies 2 (Olduvai) and 2A (Gauss). The younger one of them corresponds to the Réunion subchron (Gromme and Hay, 1971), and the older one corresponds to the X-anomaly (Heirtzler et al., 1968). Biswas et al. (1999) documented the X subchron from the Osaka Bay core (Fig. 10) and dated it at 2.44-2.45 Ma by assuming a constant accumulation rate between the G-M and lower Olduvai boundaries. In the Koolau Volcano of Oahu, the cryptochron C2r.2r-1 was documented from terrestrial lava records and dated an age that ranged from $2.68 \pm 0.25$ to $2.40 \pm 0.46 \mathrm{Ma}$ (Browne $e t$ al., 2004). Recently, Kuhlmann et al. (2006) also indicated the presence of the so-called X-event from late Neogene sediments in the southern North Sea Basin and dated it at around 2.44 Ma. Thus, the geomagnetic excursion or event around 2.42-2.45 Ma is observed from different deposits spreading over a wide area, suggesting that an excursion or event really did occur in the early Matuyama Chron.

\subsection{High-frequent occurrence of short-lived geomag- netic excursions during the Matuyama Chron}

One of the most important developments in magnetostratigraphy during the past decade has been the discovery of numerous geomagnetic excursions within the Brunhes and late Matuyama Chrons (e.g., Langereis et al., 1997; Lund et al., 2001; Singer et al., 2002; Pan et al., 2002; Yang et al., 2004). Oda (2005) reviewed the geomagnetic excursions of the Brunhes Chron, compiling a total of 23 Brunhes excursions, 18 of which were considered to be reliably determined and dated. The number of reported excursions is much fewer during the Matuyama Chron, especially the early Matuyama, than during the Brunhes Chron. Only three short events (subchrons), which include the Réunion I and Réunion II subchrons and the cryptochron C2r.2r-1 (Xsubchron), have been recognized during $630 \mathrm{ka} \mathrm{(2.58-1.95}$ $\mathrm{Ma})$, whereas a total of at least 17 reliable excursions occurred during the last $600 \mathrm{ka}$ (Oda, 2005; Lund et al., 2006). It is noted that the number of magnetic records for the Brunhes Chron is much larger than that for the Matuyama Chron. In addition, most magnetic records for the Matuyama Chron are from deep-sea sediments that often have very low accumulation rates. The fewer magnetic records together with the lower resolutions may lead to the observation of the lessfrequent occurrence of excursions during the Matuyama Chron. Our new magnetic record at a sampling interval of 5-20 cm reveal seven excursions/events during the early and middle Matuyama Chron. At the same section, Yang et al. (2004) also documented two late Matuyama excursions that were dated at about $0.89 \mathrm{Ma}$ and $0.92 \mathrm{Ma}$, respectively, by assuming a constant accumulation rate between the upper Jaramillo and M-B boundaries. These results together with the previous one reported by Channell et al. (2002) that demonstrated a large number of excursions to have occurred in the Matuyama Chron (0.9-2.2 Ma) support that the proposal that short-lived geomagnetic excursions may also be a basic characteristic of the geomagnetic field during the Matuyama Chron. 


\section{Conclusions}

A high-resolution early and middle Matuyama paleomagnetic record with detailed rock-magnetic investigation was obtained from an aeolian loess-paleosol sequence near Baoji city, the southern CLP. Our magnetostratigraphic result revises the stratigraphic position of the lower Olduvai boundary at the L27 calculated in a previous study to-at the uppermost - S26 and also reveals seven short-lived geomagnetic excursions. Assuming a constant accumulation rate between polarity boundaries, their ages are estimated to be about 1.11 Ma (E1), 1.58 Ma (E2), $1.92 \mathrm{Ma}$ (E3), $2.11 \mathrm{Ma}$ (E4), 2.25 Ma (E5), 2.35 Ma (E6), and 2.42 Ma (E7) Ma, respectively. Comparing these with the geomagnetic excursions reported from other regions, we consider that the E2 and E4 represent global excursions and conclude that more studies are necessary to support the idea that the E1, E3, E5, E6, and E7 are global. The nine Matuyama excursions observed from the Baoji section together with the eight excursions revealed in an earlier study to occur at 0.9-2.2 Ma (Channell et al., 2002) shows that the shortlived geomagnetic excursions may also be a basic characteristic of the geomagnetic field during the Matuyama Chron. Due to most excursions that are defined by a single or a few specimens in this study, further paleomagnetic studies are necessary to clarify their real existence in the CLP.

Acknowledgments. We are very grateful to Professor Toshitsugu Yamazaki and Drs. Hirokuni Oda and Qingsong Liu, who reviewed our manuscript and made numerous constructive comments and suggestions. This work was supported by Grantsin-aid from the National Natural Science Foundation of China (40602028, 40625008), Chinese Academy of Sciences (KZCX3SW-143), the China Geological Survey (200413000035), and the Ministry of Education, Culture, Sports, Science, and Technology of Japan (MEXT) (15403015). A part of this study was performed under the cooperative research program of CMCR (05B020, 06B005). TS acknowledges the JSPS for supporting his research in Japan.

\section{References}

Baksi, A. K., Comment on $"{ }^{40} \mathrm{Ar} /{ }^{39} \mathrm{Ar}$ dating of a tephra layer in the Pliocene Seneze maar lacustrine sequence (French Massif central): Constraint on the age of the Réunion-Matuyama transition and implications on paleoenvironmental archives" by Roger et al., Earth Planet. Sci. Lett., 192, 627-628, 2001.

Baksi, A. K. and K. A. Hoffman, On the age and morphology of the Réunion event, Geophys. Res. Lett., 27, 2997-3000, 2000.

Biswas, D. K., M. Hyodo, Y. Taniguchi, M. Kaneko, S. Katoh, H. Sato, Y. Kinugasa, and K. Mizuno, Magnetostratigraphy of Plio-Pleistocene sediments in a 1700-m core from Osaka Bay, southwestern Japan and short geomagnetic events in the middle Matuyama and early Brunhes Chrons, Palaeogeogr. Palaeoclimatol. Palaeoecol., 148, 233-248, 1999.

Browne, E. J., E. Herrero-Bervera and B. Singer, On the Discovery of Cryptochron C2r.2r-1 (ca. 2.42-2.44 Ma) Recorded on Koolau Volcano at Halawa: Evidence from Paleomagnetic and ${ }^{40} \mathrm{Ar} /{ }^{39} \mathrm{Ar}$ studies, AGU Fall Meeting, Abstract \#GP43B-0853, 2004.

Cande, S. C. and D. V. Kent, A new geomagnetic polarity timescale for the Late Cretaceous and Cenozoic, J. Geophys. Res., 97, 13917-13951, 1992.

Cande, S. C. and D. V. Kent, Revised calibration of the geomagnetic polarity timescale for the Late Cretaceous and Cenozoic, J. Geophys. Res., 100, 6093-6095, 1995.

Chamalaun, F. H. and I. McDougall, Dating geomagnetic polarity epochs in Réunion, Nature, 210, 1212-1214, 1966.

Channell, J. E. T. and M. E. Raymo, Paleomagnetic record at ODP Site 980 (Feni Drift, Rockall) for the past 1.2 Myrs, Geochem. Geophys. Geosyst., doi:10.1029/2002GC000440, 2003a.

Channell, J. E. T., A. Mazaud, P. Sullivan, S. Turner, and M. E. Raymo,
Geomagnetic excursions and paleointensities in the Matuyama Chron at Ocean Drilling Program Sites 983 and 984 (Iceland Basin), J. Geophys. Res., 107, 2114, doi:10.1029/2001JB000491, 2002.

Channell, J. E. T., J. Labs, and M. E. Raymo, The Réunion Subchronozone at ODP Site 981 (Feni Drift, North Atlantic), Earth Planet. Sci. Lett., 215, 1-12, 2003b.

Chauvin, A., P. Roperch, and R. A. Duncan, Records of geomagnetic reversals from volcanic islands of French Polynesia, 2, Paleomagnetic study of a flow sequence (1.2 to $0.6 \mathrm{Ma}$ ) from the Island of Tahiti and discussion of reversal models, J. Geophys. Res., 95, 2727-2752, 1990.

Clement, B. M. and D. V. Kent, Short polarity intervals within the Matuyama: transitional field records from hydraulic piston cored sediments from the North Atlantic, Earth Planet. Sci. Lett., 81, 253-264, 1987

Ding, Z. L., J. M. Sun, S. L. Yang, and T. S. Liu, Preliminary magnetostratigraphy of a thick aeolian red clay-loess sequence at Lingtai, the Chinese loess plateau, Geophys. Res. Lett., 25, 1225-1228, 1998.

Ding, Z. L., S. L. Yang, S. S. Hou, X. Wang, Z. Chen, and T. S. Liu, Magnetostratigraphy and sedimentology of the Jingchuan red clay section and correlation of the Tertiary eolian red clay sediments of the Chinese Loess Plateau, J. Geophys. Res., 106, 6399-6407, 2001.

Ding, Z. L., E. Derbyshire, S. L. Yang, Z. W. Yu, S. F. Xiong, and T. S. Liu Stacked 2.6-Ma grain size record from the Chinese loess based on five sections and correlation with the deep-sea $\delta^{18} \mathrm{O}$ record, Paleoceanography, 17, 1033, doi:10.1029/2001PA000725, 2002.

Evans, M. E. and F. Heller, Magnetism of loess/paleosol sequences: recent developments, Earth-Sci. Rev., 54, 129-144, 2001.

Fang, X. M., J. J. Li, R. Van der Voo, C. MacNiocaill, R. X. Dai, R. A Kemp, E. Derbyshire, J. X. Cao, J. M. Wang, and G. Wang, A record of the Blake event during the last interglacial paleosol in the western Loess Plateau of China, Earth Planet. Sci. Lett., 146, 73-82, 1997.

Fisher, R. A., Dispersion on a sphere, Proc. R. Soc. Lond., 217, 295-305, 1953.

Gromme, C. S. and R. L. Hay, Geomagnetic polarity epochs: Age and duration of the Olduvai normal polarity event, Earth Planet. Sci. Lett., 10, 179-185, 1971.

Guo, B., R. X. Zhu, L. P. Yue, and H. N. Wu, Cobb Mountain even recorded in Chinese loess, Science in China, Sci. China (Ser. D), 28, 327-333, 1998 (in Chinese).

Guo, Z. T., W. F. Ruddiman, Q. Z. Hao, Y. S. Qiao, R. X. Zhu, S. Z. Peng, J. J. Wei, B. Y. Yuan, and T. S. Liu, Onset of Asian desertification by 22 Myr ago inferred from loess deposits in China, Nature, 416, 159-163, 2002.

Guyodo, Y., G. D. Acton, S. Brachfeld, and J. E. T. Channell, A sedimentary paleomagnetic record of the Matuyama Chron from the Western Antarctic margin (ODP Site 1101), Earth Planet. Sci. Lett., 215, 1-12, 2001

Heirtzler, J. R., G. O. Dickson, E. M. Herron, W. C. Pitman, and X. LePichon, Marine magnetic anomalies, geomagnetic field reversals and motions of the ocean floor and continents, J. Geophys. Res., 73, 21192136, 1968

Heller, F. and T. S. Liu, Magnetostratigraphical dating of loess deposits in China, Nature, 300, 431-433, 1982.

Heller, F. and T. S. Liu, Magnetism of Chinese loess deposits, Geophys. J. R. Astron. Soc., 77, 125-141, 1984.

Heslop, D., J. Shaw, J. Bloemendal, J. Chen, J. Wang, and E. Parker, Submillennial scale variations in East Asian monsoon systems recorded by dust deposits from the North-Western Chinese Loess Plateau, Phys. Chem. Earth (A), 24, 785-792, 1999.

Heslop, D., C. G. Langereis, and M. J. Dekkers, A new astronomical timescale for the loess deposits of Northern China, Earth Planet. Sci. Lett., 184, 125-139, 2000.

Horng, C. S., M. Y. Lee, H. Palike, K. Y. Wei, W. T. Liang, Y. Iizuka, and M. Torii, Astronomically calibrated ages for geomagnetic reversals within the Matuyama chron, Earth Planets Space, 54, 679-690, 2002.

Hyodo, M., W. Sunata, and E. E. Susanto, A long-term geomagnetic excursion from Plio-Pleistocene sediments in Java, J. Geophys. Res., 97 9323-9335, 1992.

Hyodo, M., D. K. Biswas, T. Noda, N. Tomioka, T. Mishima, C. Itota, and H. Sato, Millennial- to submillennial-scale features of the MatuyamaBrunhes geomagnetic polarity transition from Osaka Bay, southwestern Japan, J. Geophys. Res., 111, B02103, doi:10.1029/2004JB003584, 2006.

Kidane, T., J. Carlut, V. Courtillot, Y. Gallet, X. Quidelleur, P. Y. Gillot, and T. Haile, Paleomagnetic and geochronological identification of the Réunion subchron in Ethiopian Afar, J. Geophys. Res., 104, 10405- 
10419, 1999

Kirschvink, J. L., The least-squares line and plane and the analysis of palaeomagnetic data, Geophys. J. R. Astron. Soc., 62, 699-718, 1980.

Kuhlmann, G., C. Langereis, D. Munsterman, R. J. van Leeuwen, R. Verreussel, J. Meulenkamp, and T. Wong, Chronostratigraphy of Late Neogene sediments in the southern North Sea Basin and paleoenvironmental interpretations, Palaeogeogr. Palaeoclimatol. Palaeoecol., 239, 426455, 2006.

Kukla, G., Loess stratigraphy in Central China, Quat. Sci. Rev., 6, 191219, 1987.

Langereis, C. G., M. J. Dekkers, G. J. de Lange, M. Paterne, and P. J. M. van Santvoort, Magnetostratigraphy and astronomical calibration of the last 1.1 Myr from an eastern Mediterranean piston core and dating of short events in the Brunhes, Geophys. J. Int., 129, 75-94, 1997.

Li, J. J., X. M. Fang, R. Van der Voo, J. J. Zhu, C. M. Niocaill, Y. Ono, B. T. Pan, W. Zhong, J. L. Wang, S. Toshinori, Y. T. Zhang, J. X. Cao, S. C. Kang, and J. M. Wang, Magnetostratigraphic dating of river terraces: Rapid and intermittent incision by the Yellow River of the northeastern margin of the Tibetan Plateau during the Quaternary, J. Geophys. Res., 102, 10,121-10,132, 1997

Liu, Q. S., S. K. Banerjee, M. J. Jackson, F. H. Chen, Y. X. Pan, and R. X. Zhu, An integrated study of the grain-size-dependent magnetic mineralogy of the Chinese loess/paleosol and its environmental significance, $J$. Geophys. Res., 108, 2437, doi:10.1029/2002JB002264, 2003.

Liu, T. S., Loess and the Environment, 251 pp., China Ocean Press, Beijing, 1985.

Liu, X. M., T. S. Liu, T. C. Xu, C. Liu, and M. Y. Chen, The Chinese loess in Xifeng, I. The preliminary study on magnetostratigraphy of a loess profile in Xifeng area, Gansu Province, Geophys. J., 92, 345-348, 1988a.

Liu, X. M., T. C. Xu, and T. S. Liu, The Chinese loess in Xifeng, II. A study of anisotropy of magnetic susceptibility of loess from Xifeng, Geophys. J. Int., 92, 349-353,1988b.

Lund, S. P., T. Williams, G. D. Acton, B. Clement, and M. Okada, Brunhes Chron magnetic field excursions recovered from Leg 172 sediments, Proc. ODP Sci. Res., 172, 1-18, 2001.

Lund, S., J. S. Stoner, J. E. T. Channell, and G. Acton, A summary of Brunhes paleomagnetic field variability recorded in Ocean Drilling Program cores, Phys. Earth Planet. Int., 156, 194-204, 2006.

Mankinen, E. A. and G. B. Dalrymple, Revised geomagnetic polarity time scale for the interval 0-5 m.y. B.P., J. Geophys. Res., 84, 615-626, 1979.

Marino, R. J. and B. B. Ellwood, Anomalous magnetic fabric in sediments which record an apparent geomagnetic field excursion, Nature, 274, 581-582, 1978.

McDougall, I. and H. Wensink, Paleomagnetism and geochronology of the Pliocene-Pleistocene lavas in Iceland, Earth Planet. Sci. Lett., 1, 232236, 1966.

McDougall, I. and N. D. Watkins, Age and duration of the Réunion geomagnetic polarity event, Earth Planet. Sci. Lett., 19, 443-452, 1973.

McDougall, I., F. H. Brown, T. E. Cerling, and J. W. Hillhouse, A reappraisal of the geomagnetic polarity time scale to 4 Ma using data from the Turkana Basin, east Africa, Geophys. Res. Lett., 19, 2349-2352, 1992.

McElhinny, M. W. and P. L. McFadden, Paleosecular variation over the past 5 myr based on a new generalized database, Geophys. J. Int., 131, 240-252, 1997.

Merrill, R. T. and P. L. McFadden, Geomagnetic field stability: Reversal events and excursions, Earth Planet. Sci. Lett., 121, 317-326, 1994.

Oda, H., Recurrent geomagnetic excursions: a review for the Brunhes normal polarity chron, J. Geograph., 114, 174-193, 2005 (in Japanese with English abstract)

Pan, Y. X., R. X. Zhu, Q. S. Liu, B. Guo, L. P. Yue, and H. N. Wu, Geomagnetic episodes of the last 1.2 Myr recorded in Chinese loess, Geophys. Res. Lett., 29, 1282, doi:10.1029/2001GL014024, 2002.

Qiang, X. K., Z. X. Li, C. M. Powell, and H. B. Zheng, Magnetostratigraphic record of the Late Miocene onset of the East Asian monsoon, and Pliocene uplift of northern Tibet, Earth Planet. Sci. Lett., 187, 8393, 2001

Raymo, M. E., W. F. Ruddiman, J. Backman, B. M. Clement, and D. G. Martinson, Late Pliocene variation in Northern Hemisphere ice sheets and North Atlantic deep water circulation, Paleoceanography, 4, 413446, 1989.

Roger, S., C. Coulon, N. Thouveny, G. Feraud, A. van Velzen, S. Fauquette, J. J. Cocheme, M. Prevot, and K. L. Verosub, ${ }^{40} \mathrm{Ar} /{ }^{39} \mathrm{Ar}$ dating of a tephra layer in the Pliocene Seneze maar lacustrine sequence (French Massif Central): constraint on the age of the Réunion-Matuyama tran- sition and implications on paleoenvironmental archives, Earth Planet. Sci. Lett., 183, 431-440, 2000.

Rolph, T. C., The Matuyama-Jaramillo R-N transition recorded in a loess section near Lanzhou, P. R. China, J. Geomagn. Geoelectr., 45, 301318, 1993.

Rutter, N. W., Z. L. Ding, M. E. Evans, and Y. C. Wang, Magnetostratigraphy of the Baoji loess-paleosol section in the north-central China Loess Plateau, Quat. Int., 7/8, 97-102, 1990.

Rutter, N. W., Z. L. Ding, M. E. Evans, and T. S. Liu, Baoji-type pedostratigraphic section, Loess Plateau, north-central China, Quat. Sci. Rev., 10, 1-22, 1991

Singer, B. S., K. A. Hoffman, A. Chauvin, R. S. Coe, and M. S. Pringle, Dating transitionally magnetized lavas of the late Matuyama Chron: Toward a new ${ }^{40} \mathrm{Ar} /{ }^{39} \mathrm{Ar}$ timescale of reversals and events, J. Geophys. Res., 104, 679-693, 1999.

Singer, B. S., M. R. Relle, K. A. Hoffman, A. Battle, H. Guillou, C. Laj, and J. C. Carracedo, Ar/Ar ages from transitionally magnetized lavas on La Palma, Canary Islands, and the geomagnetic instability timescale, $J$. Geophys. Res., 107, 2307, doi:10.1029/2001JB001613, 2002.

Spassov, S., F. Heller, M. E. Evans, L. P. Yue, and T. von Dobeneck, A lock-in model for the complex Matuyama-Brunhes boundary record of the loess/palaeosol sequence at Lingtai (central Chinese Loess Plateau), Geophys. J. Int., 155, 350-366, 2003.

Steiger, R. H. and E. Jager, Subcommission on geochronology: Convention on the use of decay constants in geo- and cosmochronology, Earth Planet. Sci. Lett., 36, 359-362, 1977.

Sun, D. H., J. Shaw, Z. S. An, and T. C. Rolph, Matuyama/Brunhes (M/B) transition recorded in Chinese loess, J. Geomag. Geoelectr., 45, 319 330, 1993.

Sun, D. H., J. Shaw, Z. S. An, M. Y. Cheng, and L. P. Yue, Magnetostratigraphy and paleoclimatic interpretation of a continuous 7.2 Ma Late Cenozoic eolian sediments from the Chinese Loess Plateau, Geophys. Res. Lett., 25, 85-88, 1998.

Sun, Y. B., S. C. Clemens, Z. S. An, and Z. W. Yu, Astronomical timescale and palaeoclimatic implication of stacked 3.6-Myr monsoon records from the Chinese Loess Plateau, Quat. Sci. Rev., 25, 33-48, 2006.

Udagawa, S., H. Kitagawa, A. Gudmundsson, O. Hiroi, T. Koyaguchi, H. Tanaka, L. Kristjansson, and M. Kono, Age and magnetism of lavas in Jokuldalur area, Eastern Iceland: Gilsa event revisited, Phys. Earth Planet. Int., 115, 147-171, 1999.

Wang, X. S., Z. Y. Yang, R. Lovlie, Z. M. Sun, and J. L. Pei, A magnetostratigraphic reassessment of correlation between Chinese loess and marine oxygen isotope records over the last 1.1 Ma, Phys. Earth Planet. Int., 159, 109-117, 2006.

Watkins, N. D., L. Kristjansson, and I. McDougall, A detailed paleomagnetic survey of the type location for the Gilsa geomagnetic polarity event, Earth Planet. Sci. Lett., 27, 436-444, 1975.

Yamazaki, T. and H. Oda, A geomagnetic paleointensity stack between 0.8 and 3.0 Ma from equatorial Pacific sediment cores, Geochem. Geophys. Geosyst., 6, Q11H20, doi:10.1029/2005GC001001, 2005.

Yang, T., M. Hyodo, Z. Yang, and J. Fu, Evidence for the Kamikatsura and Santa Rosa excursions recorded in eolian deposits from the southern Chinese Loess Plateau, J. Geophys. Res., 109, B12105, doi:10.1029/2004JB002966, 2004.

Yang, T., M. Hyodo, Z. Yang, and Z. Sun, A first paleomagnetic and rock magnetic investigation of calcareous nodules from the Chinese Loess Plateau, Earth Planets Space, 57, 29-34, 2005.

Yang, Z., B. M. Clement, G. D. Acton, S. P. Lund, M. Okada, and T. Williams, Records of the Cobb Mountain Subchron from the Bermuda Rise (ODP Leg 172), Earth Planet. Sci. Lett., 193, 303-313, 2001.

Zheng, H. B., Z. S. An, and J. Shaw, New contributions to Chinese PlioPleistocene magnetostratigraphy, Phys. Earth Planet. Int., 70, 146-153, 1992.

Zheng, H. B., T. Rolph, J. Shaw, and Z. S. An, A detailed paleomagnetic record for the last interglacial period, Earth Planet. Sci. Lett., 133, 339 351, 1995.

Zhou, L. P., F. Oldfield, A. G. Wintle, S. G. Robinson, and J. T. Wang, Partly pedogenic origin of magnetic variations in Chinese loess, Nature, 346, 737-739, 1990.

Zhou, L. P. and N. J. Shackleton, Misleading positions of geomagnetic reversal boundaries in Eurasian loess and implications for correlation between continental and marine sedimentary sequences, Earth Planet. Sci. Lett., 168, 117-130, 1999.

Zhu, R. X., Z. L. Ding, H. N. Wu, B. C. Huang, and J. Liu, Details of magnetic polarity transition recorded in Chinese loess section, $J$. Geomagn. Geoelectr., 45, 289-299, 1993. 
Zhu, R. X., C. Laj, and A. Mazaud, The Matuyama-Brunhes and Upper Jaramillo transitions recorded in a loess section at Weinan, north-central China, Earth Planet. Sci. Lett., 25, 143-158, 1994a.

Zhu, R. X., L. P. Zhou, C. Laj, A. Mazaud, and Z. L. Ding, The Blake geomagnetic polarity episode recorded in Chinese loess, Geophys. Res. Lett., 21, 697-700, 1994b.

Zhu, R. X., R. S. Coe, G. Bin, A. Robert, and X. X. Zhao, Inconsistent palaeomagnetic recording of the Blake Event in Chinese loess related to sedimentary environment, Geophys. J. Int., 134, 867-875, 1998.

Zhu, R. X., Y. X. Pan, and Q. S. Liu, Geomagnetic excursions recorded in Chinese loess in the last 70,000 years, Geophys. Res. Lett., 26, 505-508, 1999.

Zhu, R. X., B. Guo, Y. X. Pan, and Q. S. Liu, Study on the reliability of geomagnetic secular variations recorded in a loess section at Lingtai,
North-central China, Sci. China (Ser. D), 43, 1-9, 2000.

Zhu, R. X., Q. S. Liu, Y. X. Pan, C. L. Deng, and J. M. Sun, Identifying the origin of the magnetic directional anomalies recorded in the Datong loess profile, northeastern Chinese loess plateau, Geophys. J. Int., 164, 312-318, 2006.

Zijderveld, J. D. A., F. J. Hilgen, C. G. Langereis, P. J. J. M. Verhallen, and W. J. Zachariasse, Integrated magnetostratigraphy and biostratigraphy of the upper Pliocene-lower Pleistocene from the Monte Singa and Crotone areas in Calabria, Italy, Earth Planet. Sci. Lett., 107, 697-714, 1991.

T. Yang (e-mail: yangtsh@itpcas.ac.cn), M. Hyodo, Z. Yang, L. Ding, J. Fu, and T. Mishima 